\title{
Extending Cellulose-Based Polymers Application in Additive Manufacturing Technology: A Review of Recent Approaches
}

\author{
Denesh Mohan ${ }^{1,2}\left(\mathbb{D}\right.$, Zee Khai Teong ${ }^{1,2}$, Afifah Nabilah Bakir ${ }^{1,2}$, Mohd Shaiful Sajab ${ }^{1,2, *(D)}$ and \\ Hatika Kaco $^{3}$ \\ 1 Research Center for Sustainable Process Technology (CESPRO), Faculty of Engineering and Built \\ Environment, Universiti Kebangsaan Malaysia, Bangi 43600, Selangor, Malaysia; \\ denesh.mohan@gmail.com (D.M.); teongzeekhai@gmail.com (Z.K.T.); \\ afifahnabilahbakir@gmail.com (A.N.B.) \\ 2 Department of Chemical and Process Engineering, Faculty of Engineering and Built Environment, \\ Universiti Kebangsaan Malaysia, Bangi 43600, Selangor, Malaysia \\ 3 Kolej GENIUS Insan, Universiti Sains Islam Malaysia, Bandar Baru Nilai, \\ Nilai 71800, Negeri Sembilan, Malaysia; hatikakaco@usim.edu.my \\ * Correspondence: mohdshaiful@ukm.edu.my; Tel.: +60-3-8921-6425
}

Received: 17 July 2020; Accepted: 18 August 2020; Published: 20 August 2020

\begin{abstract}
The materials for additive manufacturing (AM) technology have grown substantially over the last few years to fulfill industrial needs. Despite that, the use of bio-based composites for improved mechanical properties and biodegradation is still not fully explored. This limits the universal expansion of AM-fabricated products due to the incompatibility of the products made from petroleum-derived resources. The development of naturally-derived polymers for AM materials is promising with the increasing number of studies in recent years owing to their biodegradation and biocompatibility. Cellulose is the most abundant biopolymer that possesses many favorable properties to be incorporated into AM materials, which have been continuously focused on in recent years. This critical review discusses the development of AM technologies and materials, cellulose-based polymers, cellulose-based three-dimensional (3D) printing filaments, liquid deposition modeling of cellulose, and four-dimensional (4D) printing of cellulose-based materials. Cellulose-based AM material applications and the limitations with future developments are also reviewed.
\end{abstract}

Keywords: 3D printing; 4D printing; additive manufacturing; cellulose; biopolymer

\section{Introduction}

The world population increases by 227,400 people a day, and this situation increases the burden on the earth as the world population is expected to reach 10.74 billion by 2100 , which can be extremely detrimental from an environmental perspective [1]. Due to the increase in population, intense research has been done to cope with the manufacturing demands; consequently, unsustainable production from non-renewable resources resulted in significant global pollution and climate changes [2]. Efforts have been taken in material research to manufacture durable materials with a lower tendency to degrade. However, with the high utilization of materials, the end-of-life of the materials has to be managed to conserve the environment. Only $10 \%$ of plastics are recycled, $60 \%$ is dumped in landfills, and $30 \%$ are unaccounted for, which can be discarded in any part of the environment, thus resulting in environmental issues [3]. By 2050, the plastic industry may need $20 \%$ of the crude oil supply to accommodate plastic production if the trend remains unchanged [4]. Thus, the UK government came up with the aim of zero avoidable waste 2050 to have sustainable production and improve the environmental condition [5]. 
The decrease in fossil fuel resources and the increase in plastic consumption drive the search for alternative resources and technologies for more sustainable and environmentally friendly plastic production. Sustainable plastic materials should be produced from renewable resources without damaging the environment, easily recycled, and biodegradable under certain environmental conditions with low energy consumption [6]. Biodegradable plastics and composites manufactured from renewable resources such as biomass are considered as the future materials that could replace polymers that are currently produced from petrochemical feedstock [7].

Lignocellulosic biomass, which presents in the form of discarded industrial waste and agricultural residues, represents the most abundant and sustainable resource available [8]. The main constituents in the lignocellulosic biomass are cellulose, lignin, and hemicellulose and the compositions differ for different types of biomass $[9,10]$. Cellulose and hemicellulose comprise polysaccharide chains, whereas lignin consists of irregular three-dimensional and branched phenolic polymers, and the material is also amorphous in nature [11,12].

Cellulose is known to be the most abundantly available component of biomass that covers up to $50 \mathrm{wt}$. \% of lignocellulosic biomass [13]. Many studies have been carried out on cellulose as it is one of the most sustainable and renewable materials with novel applications to improve certain products. Various types of cellulose can be used to synthesize nanocellulose from the cellulose, such as cellulose nanofibrils (CNF), cellulose nanocrystals (CNC), and bacterial nanocellulose (BNC). These nanocellulose products vary in terms of properties, morphology, and crystallinity, depending on the extraction method and biomass used $[14,15]$. The biocompatibility and biodegradability of nanocellulose drive researchers to study the use of nanocellulose in wastewater treatment, packaging, drug delivery, and biosensors [16]. The utilization of cellulose fiber as the feedstock for injection molding has now expanded to AM, which is among the coveted industries in the world [17].

$\mathrm{AM}$ is the process of manufacturing materials layer by layer to fabricate precise three-dimensional (3D) models using data from computer-aided design (CAD) software [18]. Currently, various AM technology are widely adopted in industrial and domestic applications due to ease of product fabrication. Most applications are limited to smaller scales that limit waste production and energy consumption without the usage of bigger machines [19]. AM has expanded to various industries, including metal, ceramic, and medical applications, and the current focus of this technique is bioprinting cardiovascular application, which involves 3D-printed heart valves [20-23]. Various materials to be used in AM have been developed, such as polymers, metals, and composites; however, most of these materials are harmful to humans and the environment due to the release of volatile organic compounds [23-26].

Therefore, many naturally derived polymers are used in current studies for the preparation of scaffolds by 3D printing due to the large potential in biomedical applications, particularly the replacement and regeneration of cells, tissues, or organs [27-29]. Various studies have been conducted in this field using different formulations of collagens, alginates, and chitosan, as these materials are well-known natural sources of polymers [30-32]. AM of cellulose-based materials is a promising option due to the renewable source and low cost of extraction with lower environmental degradation.

In this manuscript, cellulose-based three-dimensional (3D) printing and four-dimensional (4D) printing materials are reviewed. Then, 3D printing technologies and developed materials are discussed. Next, mechanical and physical characterization of AM-fabricated parts are reviewed, in addition to the improvement done to meet the industrial application needs. Cellulose as a biopolymer product and its incorporation in 3D printing filaments are studied. Liquid printing of cellulose and the rheological changes done to ease the extrusion process and maintain the shape fidelity of the constructed part are discussed, with the emphasis given on the research conducted in the last five years. The contribution of cellulose-based 3D printing materials in biomedical engineering, electronic engineering, textiles, food, and food packaging industries are presented. 4D printing technology and the smart materials developed in recent times are discussed briefly. Cellulose-based smart materials and cellulose-based $4 \mathrm{D}$ printing materials are reviewed. Finally, the limitations and future trends of cellulose-based AM materials are also provided. 


\section{Polymer-Based Additive Manufacturing}

\subsection{Types of Additive Manufacturing Technologies}

AM technologies are the essential part of the whole 3D printing, bridging the 3D models, materials, and final applications based on the products needed by the industry. Originally, 3D printers were used to produce one or two fast prototype models to help developers fix faults and change the product as a fast prototyping solution. Different technologies have been developed by varying the technique of printing product on the build platform and the materials used for printing.

By referring to ASTM Standard F2792, the American Society for Testing and Materials (ASTM) has documented 3D printing technologies into seven categories, namely material extrusion, powder bed fusion, vat photopolymerization, direct energy deposition, binder jetting, material jetting, and sheet lamination, as shown in Figure 1 [33,34]. AM technologies of polymer-based materials are reviewed in Table 1.

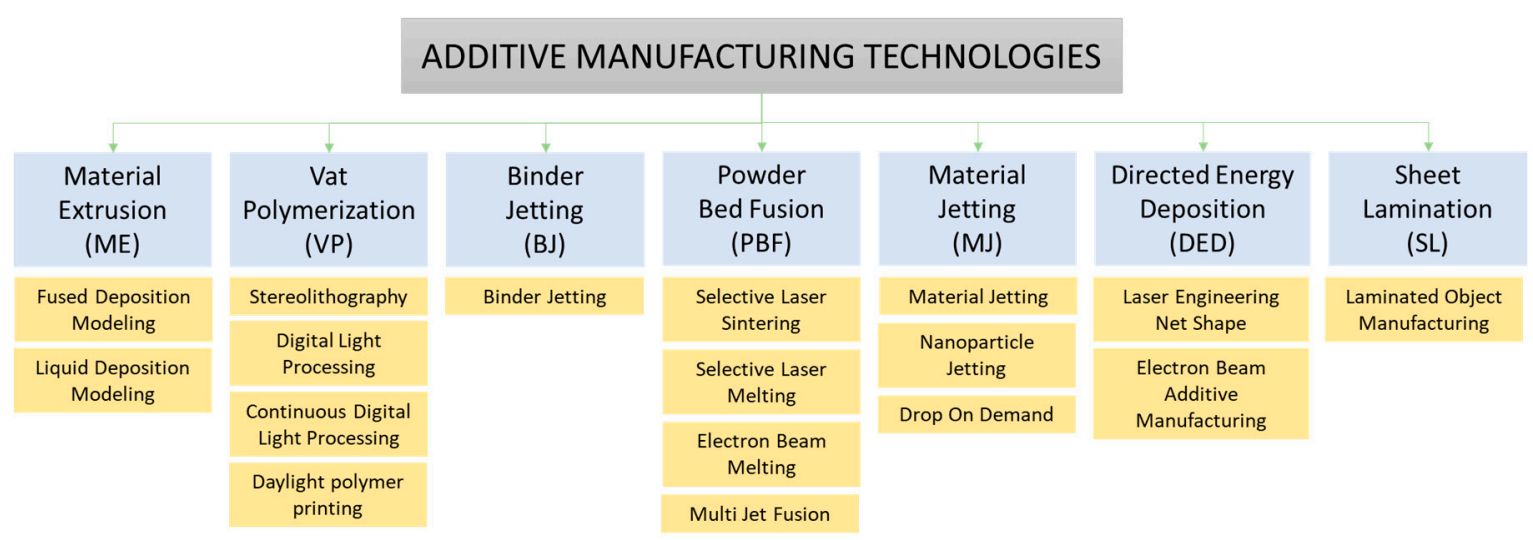

Figure 1. Additive manufacturing technologies category adapted from [33,34].

Table 1. The advantages AM technologies of polymer-based materials and its potential applications.

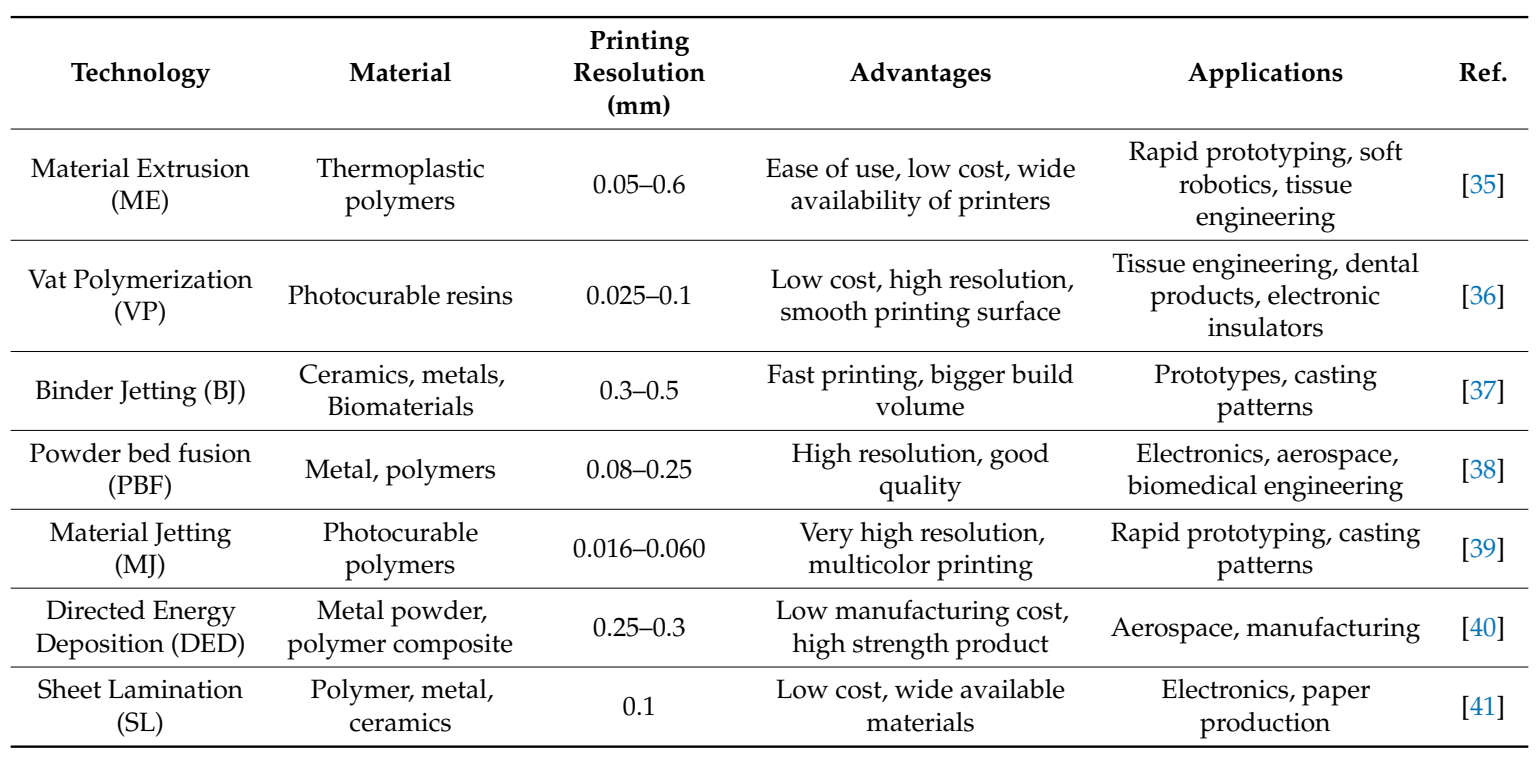

\subsection{Biodegradable Polymers for Additive Manufacturing}

Polymer shows a major contribution in AM, whereby parts produced from the polymer are recorded with $51 \%$ contribution, $29 \%$ metal and polymer, and $19.8 \%$ is metal product $[42,43]$. Among the many available AM techniques producing 3D-printed polymers, FDM is mainly used for fabrication. FDM 3D print polymer has become an affordable technology. The cost of a commercial 3D printer in the 
market and the filament polymer is inexpensive. The two most common material in FDM are ABS and PLA, but these materials have their advantages and drawbacks that need to be solved. PLA printing is known for its green material, biodegradability, low warping, and good surface print; however, the method produces products with lower mechanical properties and low heat resistance, which affect their application in industries. Meanwhile, ABS products have better mechanical properties and thermal properties, but an unpleasant odor is produced during printing, which affects the health of the user and the environment [44].

Due to the feasibility of this technology, it has been used as part of educational kits, prototypes, visual aids, and presentation models (see Figure 2). However, due to the lack of technical skills and quality of the 3D printer, the end-user tends to produce massive waste from supportive material, failed products, and broken plastic parts. The potential of AM as exploited technology to build the future is undeniable. However, this emerging technology has started making a new pathway of waste generation.

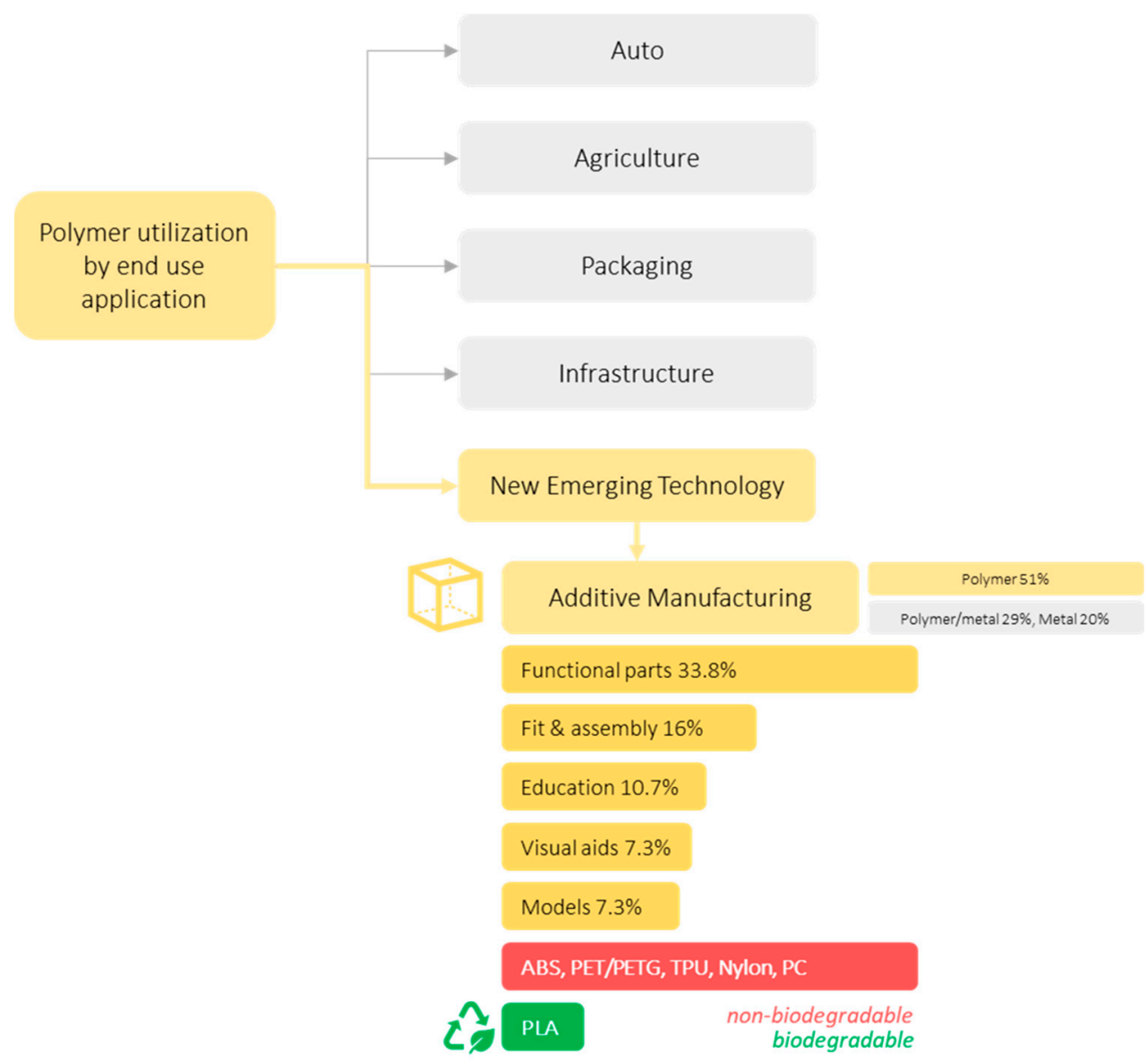

Figure 2. A new threat of plastic waste generation from additive manufacturing.

Over the last, the production of plastics has increased tremendously due to various types of applications mainly focusing on packaging, thus generating uncontrollable waste that degrades the environment. Most of the plastics used commercially are made from petroleum resources, one of the non-renewable sources of energy. Most of the used plastics are not managed well: most are dumped as waste, with only a small amount being recycled. For instance, about $1.5-4 \%$ or $5-13$ million tonnes of plastic are dumped in the ocean every year [45]. The utilization of waste by the conversion to biopolymers is an effective approach of conserving the environment, and the practice is being focused on immensely in recent years. Biopolymers are defined as the naturally-derived polymers from living organisms or chemically synthesized from renewable matter, which can be used to replace conventional 
plastics [46]. According to ASTM D883, biodegradable plastic is defined as plastic degraded through degradation by naturally occurring organisms, such as bacteria, fungi, and algae [47].

Polymer biodegradation is a complicated process where many biological, chemical, and mechanical processes are involved in converting polymers to smaller molecular chains and then further converted to carbon dioxide and water [48]. Biodegradation occurs through three essential processes: biodeterioration, biofragmentation, and assimilation. Biodeterioration is the modification of physical and chemical properties polymer owing to the growth of microorganisms throughout the polymer surfaces. Biofragmentation is the breaking down of polymers into simpler structures, such as oligomers and monomers by microorganisms present. The final step is assimilation, where microorganisms are fed with necessary living sources from the breaking down of polymers, followed by the conversion of the carbon in the plastic to carbon dioxide, water, and biomass. Among polymer biodegradation factors are the chemical structure, the length of the polymer chain, the complexity of the polymeric formula, and the crystallinity of the polymer [49].

To introduce a biodegradable-based polymer in the 3D printing industry, modifications need to be intensively done so that polymers will be usable in various AM techniques. Many industries have been working on utilizing 3D-printed polymers to enhance the product properties by the addition of composites to have the desired properties. Thus, 3D printing of natural and synthetic polymers with composites has progressed immensely in recent years, together with the discovery of new materials. The challenges in 3D printing include the aspects from controlling the flowability to produce good extrusion, the mechanical properties, to the adhesion between layers in order to have a strong printed part. Despite these challenges, the complexity of the product and freeform fabrication are the driving factors to produce a 3D-printed product with less waste. Hence, since PLA in one of the biodegradable synthetic polymers, much attention is given to the study of the incorporation of different types of fillers (see Table 2) to improve the mechanical properties and the biodegradability of the commercially available polymers.

However, continuous study must be done to incorporate fillers at a higher percentage with the improved porosity and shrinkage for the developed materials to meet the required standards. The focus will be on the adaptation of 3D printing for industrial applications with the development of new 3D printing biodegradable-based polymer composites. Subsequently, the limited option of biodegradable filament in 3D printing can be catered by formulating biodegradable-based polymers as a new filament in the market. On the other hand, natural polymers such as chitosan, soy protein, and starch are also being studied intensively for biomedically applications owing to the good compatibility towards living cells for cell generations [50,51].

Table 2. The modification approaches on the biodegradable of PLA.

\begin{tabular}{ccccc}
\hline Filler & Filler Fraction (\%) & $\begin{array}{c}\text { Composite Tensile } \\
\text { Strength (MPa) }\end{array}$ & Difference (\%) & Ref \\
\hline Modified carbon fiber & 34 & 91.0 & +225.0 & {$[52]$} \\
Carbon fiber & 28 & 61.4 & +36.8 & {$[53]$} \\
Graphene nanoplatelets & 10 & 40.2 & +27.2 & {$[54]$} \\
Rice husk & 20 & 53.0 & +18.3 & {$[55]$} \\
Ceramics & 40 & 43.2 & +1.9 & {$[56]$} \\
Poplar fibers & 20 & 54.0 & 0.0 & {$[57]$} \\
Copper & 40 & 40.3 & -4.9 & {$[56]$} \\
Aluminum & 40 & 40.2 & -5.1 & {$[56]$} \\
Calcium carbonate & 20 & 37.0 & -17.8 & {$[58]$} \\
Lignin & 40 & 45.65 & -21.9 & {$[59]$} \\
Wood fiber & 60 & 13.49 & -63.9 & {$[60]$} \\
Cork granules & 50 & 10.4 & -82.6 & {$[61]$} \\
\hline
\end{tabular}




\section{Cellulose-Based Polymers in 3D Printing Technology}

The main principles of both green chemistry and green engineering is focusing on the prevention of new generation waste. The prevention can be started in this new emerging technology by introducing sustainable and biodegradable materials in 3D printing applications. As early as possible, the polymerbased material used in the AM should pursue cradle to cradle design. On top of mechanical properties, the capability of cellulose-based polymer as bio-filler and hydrogel matrix will be a key to developing sustainable additive manufacturing (see Figure 3).

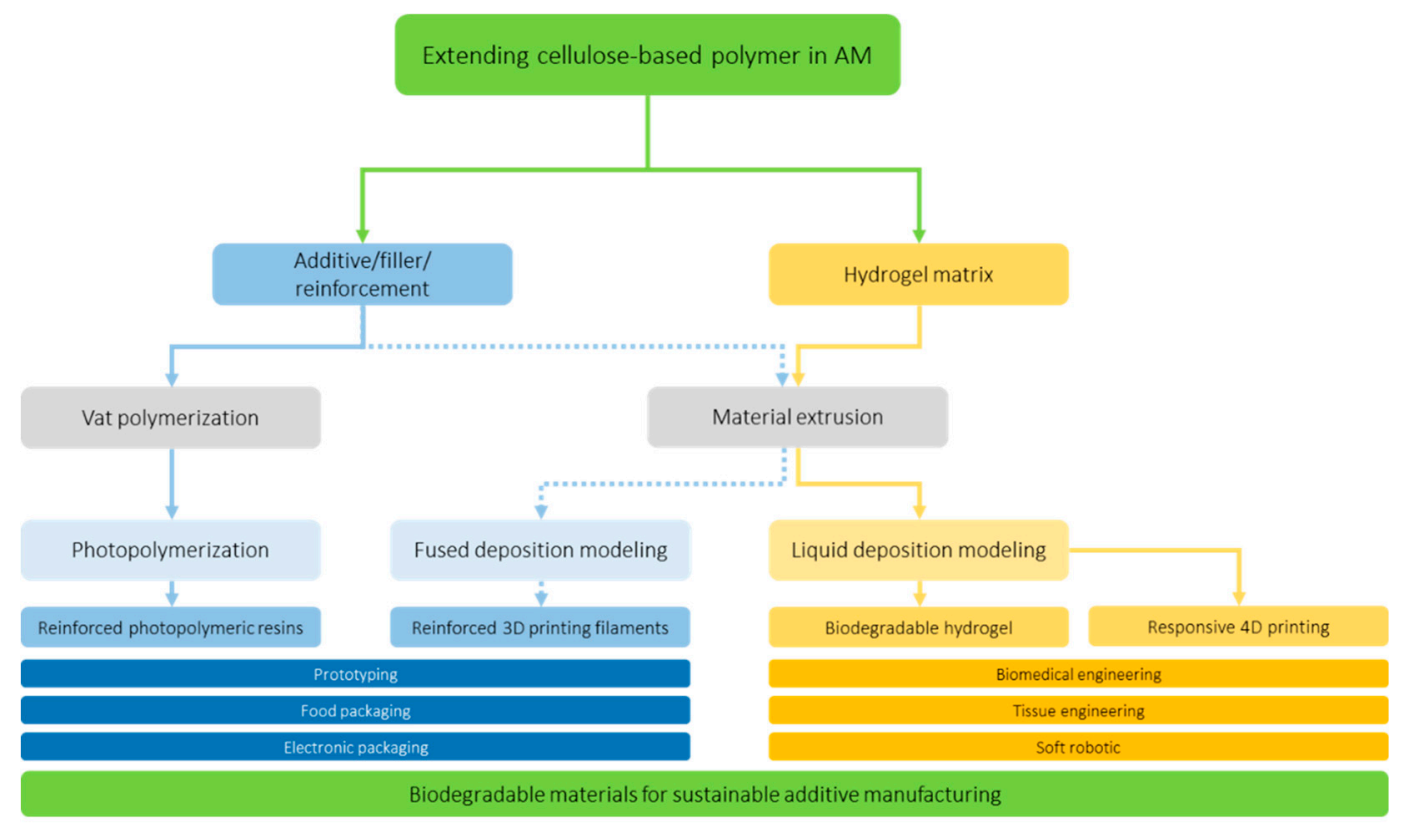

Figure 3. Possible pathway of extending cellulose-based polymer as green and biodegradable materials for sustainable additive manufacturing.

\subsection{Cellulosic Biopolymer}

Modification and reinforcement of cellulose into biopolymers are an ever-increasing trend in recent times owing to its biodegradability and low cost of extraction. Cellulose, which is a type of natural biopolymer, is the most abundant component present at the highest percentage in lignocellulosic biomass. Cellulose is a linear polysaccharide that consists of $\beta-1,4$-glycosidic bond connecting two $\beta$-d-glucopyranose with a degree of polymerization from hundreds to thousands [11]. Hydrogen bonds formed through the high number of hydroxyl groups and Van der Waals interaction are present on glucose rings, thus resulting in the crystallization of few cellulose chains into fibrils and structural regions of crystalline and amorphous regions, which give high mechanical properties and biocompatibility. Three hydroxyl groups present in one cellulose monomeric unit contribute to cellulose properties, such as surface hydrophilicity, biodegradability, and chirality [62]. Modifications can be done on cellulose due to the presence of hydroxyl groups to obtain cellulose derivatives through a number of reactions, such as esterification, etherification, and carboxymethylation [63].

Polymer composites reinforced with microcrystalline cellulose (MCC) have excellent properties, such as high tensile strength, low density, and different morphologies, but suffer from the issues of surface compatibility, moisture absorption, and poor wettability. MCC is a type of cellulose obtained from partial depolymerization of alpha-cellulose with acids, such as hydrochloric acid and sulfuric acid $[64,65]$. The amorphous phase of cellulose will be hydrolyzed, thus producing more crystalline and shorter fragments. The hydrolysis process parameters, including temperature, time, acid concentration, and fiber-to-acid ratio determine the mechanical properties of MCC. The reinforcement of MCC obtained from acid hydrolysis of wheat straw in the PLA matrix showed enhanced mechanical 
properties with an increment of tensile modulus and tensile strength by $27 \%$ and $8.4 \%$, respectively [66]. Furthermore, the incorporation of MCC to concrete was studied owing to the high mechanical strength of MCC. The addition of MCC at $1 \mathrm{wt} . \%$ of cement in the concrete improved the buildability, as well as increased the compressive and flexural properties by $18.6 \%$ and $12.5 \%$, respectively [67]. By looking at the trend of biocomposites, extensive research is being carried out using MCC to develop products for pharmaceutical, food, cosmetic, cement, and packaging material industries [68].

Carboxymethyl cellulose (CMC) is a type of cellulose derived with carboxymethyl groups $\left(-\mathrm{CH}_{2} \mathrm{COOH}\right)$ bonded to the hydroxyl groups of the cellulose monomer and often substituted with sodium to form sodium carboxymethyl cellulose. CMC is synthesized through the reaction with aqueous sodium hydroxide $(\mathrm{NaOH})$ solution, followed by subsequent alkalization, carboxymethylation, and neutralization. The alkalization of $\mathrm{CMC}$ utilizes $\mathrm{NaOH}$, carboxymethylation uses sodium chloroacetic acid at $60{ }^{\circ} \mathrm{C}$, and neutralization uses ethanol at $96 \%$ concentration [69]. The increase of oxidized CMC percentage by four times in the CMC-CNF-xylan biocomposite managed to increase tensile strength by two times, and also improved tensile modulus [70]. CMC is commonly used in the pharmaceutical industry as a binder because CMC has the ability to form tough tablets, utilized for drug delivery and tissue engineering, and used in paper and textile industries [71,72].

Three types of nanocellulose (i.e., CNC, CNF, and bacterial cellulose (BC)) can be derived from cellulose through various methods, such as acid hydrolysis, high-speed homogenization, and bacterial process. Nanocellulose is being explored extensively owing to its high mechanical properties, low density, reinforcing properties, and biodegradability. CNC is derived from the isolation of crystalline regions present in cellulose with a combination of chemical and mechanical treatments. $\mathrm{CNC}$ can be viewed as stiff rod-like particles under the microscope; hence, it is known as cellulose whiskers or microcrystallites. Acid hydrolysis is a widely utilized method for the isolation of CNC from cellulose, and the highest yield of CNC depends on the optimum acid concentration of 56-60 wt. \% and temperature of $60-70{ }^{\circ} \mathrm{C}$, where high concentration and temperature will lead to the dissolution of cellulose [73]. Various methods have been considered in the isolation of CNC as a substitute to the acid hydrolysis method due to the difficult treatment of acid waste [74]. CNC possesses tremendously good properties such as high tensile strength, low density, optical transparency, and high surface area, which are suitable for many applications, such as biosensors, drug delivery, and water absorption [75]. The addition of $2 \mathrm{wt}$. \% CNC in urea-formaldehyde adhesive for fabrication of medium-density fiberboard reduced formaldehyde emission by $17 \%$ and enhanced the mechanical properties of the fiberboard [76].

$\mathrm{CNF}$ is another type of nanocellulose isolated from cellulose through mechanical treatment. CNF can be produced using high-speed homogenization, producing web-like nanofibrils consisting of both crystalline and amorphous regions [77,78]. The high shearing force yields CNF having shear-thinning behavior with a high aspect ratio $[79,80]$. The electrospinning of CNF, PLA, and polybutylene succinate (PBS) can generate a composite with cell attachment and proliferation process that could be suitable for tissue regeneration applications with better mechanical properties and biodegradability due to the reinforcement by CNF [81]. The unique properties of CNF have been employed throughout various applications, such as food, drug delivery, electronic, tissue engineering, and cosmetic applications.

$\mathrm{BC}$ is a biodegradable nanocellulose synthesized through the microbial activity on cellulose. Oxidative fermentation of bacteria such as Gluconacetobacter, Sarcina, and Agrobacterium in non-synthetic or synthetic media will form cellulose fibrils with network-like structures that possess high surface area and mechanical properties [82]. Different bacteria can be used with the manipulation of culture conditions to synthesize BC in different shapes, such as gels and granules [83]. Surface grafting through the acetylation of $B C$ to nullify the hydrophilicity of $B C$ was able to disperse $B C$ homogeneously in the PLA matrix and improve the stiffness of the nanocomposite while maintaining the tensile strength compared to the neat PLA [84]. Surface grafting through the acetylation of BC to nullify the hydrophilicity of $\mathrm{BC}$ was able to disperse $\mathrm{BC}$ homogeneously in the PLA matrix and improve the stiffness of the nanocomposite while maintaining the tensile strength compared to the neat PLA [83]. 
Cellulose acetate (CA) is one of the most valuable cellulose derivatives that is biodegradable and non-toxic. CA can be synthesized through the acetylation process by the reaction of cellulose with acetic acid and acetic anhydride using sulfuric acid as the catalyst [85]. The synthesized CA has excellent electrical conductivity, chemical, and thermal resistant properties that can be obtained with low cost, which encourages the use of CA in many applications, especially in the biomedical industry. The addition of $20 \mathrm{wt}$. \% CA in the PVA matrix improved the porosity of the films, and the antibacterial activity of the composite was observed with the incorporation of vancomycin, which can be applied in wound healing applications [86].

\subsection{Fused Deposition Modeling Filament}

Cellulose particles in micro/nano size can be incorporated in 3D printing filaments to increase the mechanical properties of the printed products. This is due to the properties of cellulose, especially nanocellulose that possesses high surface area, high mechanical properties, and shear-thinning properties, thus making cellulose suitable for many applications. The 3D printing of cellulose has been mostly done using two approaches: filament extrusion and liquid deposition modeling.

However, major issues arise in the compatibility of cellulose and polymer matrix due to the hydrophilicity of cellulose and hydrophobicity of the polymer matrix, in which cellulose requires surface modification to improve the compatibility and dispersion of cellulose in the polymer matrix. One of the earliest surface grafting methods of cellulose was performed using a titanate coupling agent that was incorporated in PLA by casting and melt extrusion [87]. The hydrophilicity of cellulose was reduced by surface modification, which made the cellulose compatible with the hydrophobic PLA matrix by reducing the water intake of the modified cellulose compared to unmodified cellulose. The modified cellulose increased the crystallinity of the composite with increased storage modulus, indicating better mechanical properties.

The other type of surface modifier that can be used is PEG that acts as a plasticizer to nanocellulose as it can promote uniform adhesion and dispersion of nanocellulose in the PLA matrix. Addition of nanocellulose was able to improve the composite thermal stability, whereas nanocellulose/PEG addition improved the crystallization rate, which is vital during printing for the buildability of printed products [88]. Furthermore, 3,6-dimethyl-1,4-dioxane-2,5-dione as L-lactide monomer was surface grafted on CNF also was able to improve the homogeneity in the PLA matrix, and it was found that the crystallinity of the extruded filaments increased about $100 \%$ [89]. On the other hand, PLA, poly(3-hydroxybutyrate), and CNC crosslinked with dicumyl peroxide was investigated for its properties through various fabrication techniques, as shown in Figure 4 [90]. While the dicumyl peroxide addition improved the homogeneity of CNC in the polymer matrix and enhanced the interfacial adhesion between the polymers. Incorporation of CNC was essential to maintain the thermal stability and delaying the degradation process during the extrusion, compression molding, and 3D printing, as low thermal stability was observed in the composite without CNC. The composites that were processed as filaments demonstrated the best thermal and mechanical properties compared to compression and 3D printing owing to better surface grafting of CNF and compatibility in the polymer matrix.

Pickering emulsion approach is also a new method to incorporate TEMPO oxidized BC into PLA for a better dispersion of cellulose in polymer matrix [91]. Upon investigation of the crystallinity of the matrix subjected to $1.5 \%$ of TEMPO oxidized BC, the crystallinity increased by 2.16 times compared to PLA. The mechanical properties of the composite also increased tremendously due to the better dispersion of nanocellulose in the polymer matrix. This approach can also be used for other types of nanocellulose, particularly for 3D printing of biodegradable products.

Some types of cellulose do not require surface grafting; for example, hydroxypropyl methylcellulose (HPMC) derived from vegetable fibers can be incorporated readily in commercial polymer owing to the presence of the methyl group that can enhance the interfacial adhesion in the polymer matrix [92]. The mechanical strength of the 5\% HPMC/PLA filament had tensile strength 
comparable to PLA with the contact angle enhanced up to $30^{\circ} \mathrm{C}$, and the improved thermal properties can pave the way for application of this composite for FDM printing in biomedical applications.

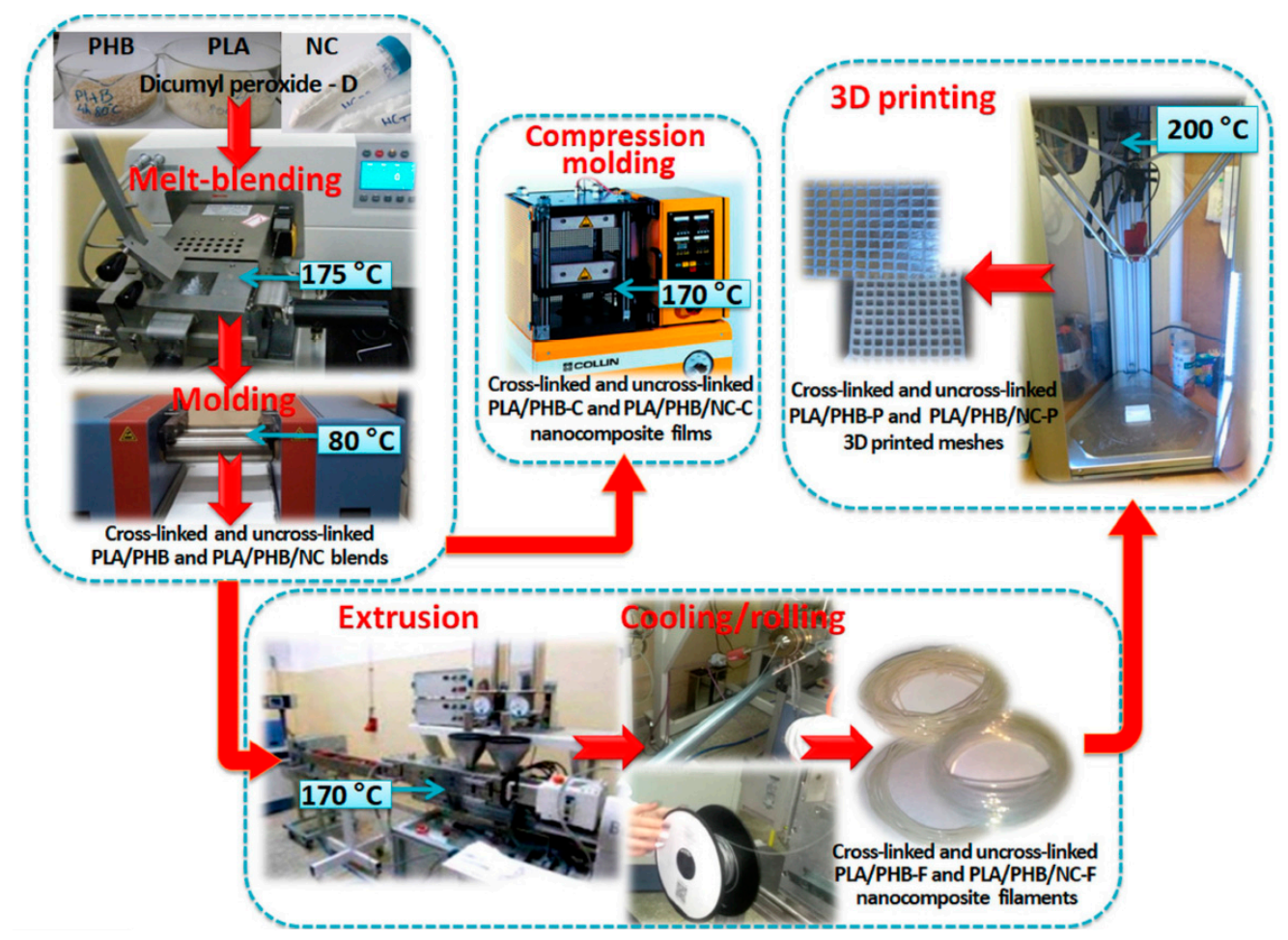

Figure 4. Schematic representation of PLA/PHB blends and nanocomposites preparation and processing of films, filaments, and 3D-printed meshes [90].

Biodegradable cellulose-based filaments without the presence of commercial polymers are essential for many applications, such as biomedical engineering. Cellulose-based filaments containing $50 \%$ CA and 50\% cornstarch were extruded using a single-screw extruder, and the printing was carried out at the extrusion temperature between 230 and $240{ }^{\circ} \mathrm{C}$ with different flow rates of $80 \%$ and $90 \%$. The sample heated at $230^{\circ} \mathrm{C}$ with $90 \%$ material flow showed the best properties due to the lower voids present, better structural homogeneity, and good interlayer adhesion; in addition, higher printing temperature also led to poor adhesion and degradation of the sample. This method will be essential in the manufacturing of medical products for drug delivery and tissue engineering as it is highly biocompatible [93].

Furthermore, post-processing of the 3D printed cellulose composite part can be considered to match the industrial standard applications, as it can enhance the mechanical properties. The crystallinity of the printed part can be enhanced up to $200 \%$ through post processing if compared to neat polymer matrix, which will enhance the mechanical and thermal properties of the sample [89]. Another study on the 3D-printed product proved that the incorporation of grafted CNF with post-processing by annealing improved the static flexural modulus of the printed product by 151.94 times at $70 \%$ for $3 \%$ composite compared to the neat PLA without annealing [94]. Chemical post-processing can also be considered to reinforce the commercial polymer, as impregnation of $\mathrm{CNC}$ in methacrylate resin on an ABS printed sample was able to enhance the mechanical properties of the printed part [95]. Interfacial adhesion was improved upon impregnation, as indicated in the morphological analysis. The mechanical and thermal properties of the sample improved through the reinforcement of CNC and better dispersion demonstrated isotropic behavior. Table 3 reviews the typical reinforcement of cellulosic materials in commercial thermoplastic filaments for the FDM printing technique. 
Table 3. Recent findings on the cellulose composited in thermoplastic filament for FDM extrusion.

\begin{tabular}{|c|c|c|c|c|c|c|}
\hline $\begin{array}{l}\text { Polymer/Cellulose } \\
\text { Composition (wt } \%)\end{array}$ & $\begin{array}{l}\text { Extrusion } \\
\text { Technique }\end{array}$ & FDM Printer & $\begin{array}{l}\text { Nozzle } \\
\text { Temp. }\left({ }^{\circ} \mathrm{C}\right)\end{array}$ & $\begin{array}{l}\text { Nozzle } \\
\text { Diameter } \\
(\mathrm{mm})\end{array}$ & Improvements. & Ref. \\
\hline $\begin{array}{c}73.5 \% \text { PLA, } 24.5 \% \text { PHB, } \\
1 \% \text { CNC, } 1 \% \text { dicumyl } \\
\text { peroxide }\end{array}$ & Twin-screw & $\begin{array}{l}\text { WASP Delta } \\
2040 \text { Turbo } 2\end{array}$ & 200 & 0.4 & $\begin{array}{l}\text { Mechanical properties } \\
\text { and thermal stability }\end{array}$ & [90] \\
\hline $\begin{array}{l}\text { 93\% PLA, } 7 \% \\
\text { Hydroxypropyl } \\
\text { methylcellulose }\end{array}$ & Single-screw & Ender-3S & 200 & 0.4 & $\begin{array}{l}\text { Thermal properties and } \\
\text { contact angle }\end{array}$ & [92] \\
\hline $\begin{array}{l}70 \% \text { PLA, } 25 \% \text { recycled } \\
\text { PLA, } 5 \% \text { MCC, } 0.5 \mathrm{phr} \\
\text { epoxy-based chain } \\
\text { extender }\end{array}$ & Twin-screw & LulzBot TAZ 6 & 200 & 0.5 & $\begin{array}{l}\text { Tensile strength, } \\
\text { modulus and Izod } \\
\text { impact strength }\end{array}$ & [96] \\
\hline $\begin{array}{c}95 \% \text { PLA, } 5 \% \text { Hemp } \\
\text { powder }\end{array}$ & Single-screw & Ultimaker 3 & 180 & 0.4 & $\begin{array}{l}\text { Elastic modulus, tensile } \\
\text { strength }\end{array}$ & [97] \\
\hline $\begin{array}{l}95 \% \text { ABS, } 5 \% \\
\text { CNC/Silica } \\
\text { nanohybdrids }\end{array}$ & Twin-screw & $\begin{array}{l}\text { S1 Architect } \\
\text { 3D }\end{array}$ & 235 & 0.3 & $\begin{array}{l}\text { Reduced warping, } \\
\text { tensile strength, and } \\
\text { layer adhesion }\end{array}$ & [98] \\
\hline $\begin{array}{l}90 \% \text { Polycaprolactone, } \\
\text { (PCL), } 10 \% \text { MCC }\end{array}$ & Single-screw & Prusa i3 & 210 & 0.4 & $\begin{array}{l}\text { Mechanical strength } \\
\text { and cell proliferation }\end{array}$ & [99] \\
\hline $\begin{array}{l}80 \% \text { Polypropylene } \\
\text { (PP), } 20 \% \text { cellulose } \\
\text { waste materials }\end{array}$ & Twin-screw & $\begin{array}{l}\text { Lulzot Taz } 6 \\
\text { MEAM }\end{array}$ & 220 & 0.8 & $\begin{array}{l}\text { Storage and elastic } \\
\text { modulus }\end{array}$ & [100] \\
\hline $\begin{array}{l}95 \% \text { ABS, } 5 \% \text { Oil palm } \\
\text { fibre }\end{array}$ & Single-screw & UP Plus 2 & N/A & 0.4 & $\begin{array}{l}\text { Tensile strength and } \\
\text { elastic modulus }\end{array}$ & [101] \\
\hline $80 \%$ PVA, $20 \%$ CNC & Single-screw & $\begin{array}{l}\text { Sharebot } \\
\text { Next } \\
\text { Generation }\end{array}$ & 230 & 0.35 & $\begin{array}{l}\text { Tensile strength and } \\
\text { thermal properties }\end{array}$ & [102] \\
\hline $\begin{array}{l}90 \% \text { ABS, } 10 \% \text { Lignin } \\
\text { coated CNC }\end{array}$ & Single-screw & Solidoodle 3 & 210 & 0.35 & $\begin{array}{c}\text { Mechanical and thermal } \\
\text { properties }\end{array}$ & [103] \\
\hline $70 \%$ PLA, $30 \%$ CNF & Single-screw & Solidoodle 3 & 180 & 0.35 & $\begin{array}{l}\text { Tensile strength and } \\
\text { elastic modulus }\end{array}$ & [104] \\
\hline $\begin{array}{c}87 \% \text { PLA, } 13 \% \\
\text { polybutylene adipate } \\
\text { terephthalate (PBAT), } \\
40 \text { phr Hemp hurd }\end{array}$ & Twin-screw & 3D da Vinci 1.0 & 200 & 0.4 & $\begin{array}{l}\text { Flexural modulus and } \\
\text { dimensional accuracy }\end{array}$ & [105] \\
\hline $\begin{array}{c}50 \% \text { Poly } \\
\text { (e-caprolactone), } 50 \% \\
\text { cocoa shell waste }\end{array}$ & Single-screw & $\begin{array}{l}\text { Prusa i3 } \\
\text { Hephestos }\end{array}$ & 120 & 0.3 & $\begin{array}{c}\text { Mechanical and thermal } \\
\text { properties }\end{array}$ & [106] \\
\hline
\end{tabular}

\subsection{Vat Photopolymerization}

Apart from FDM, VP has also been extensively improved through the development of liquid photopolymer resin due to the accuracy of the printed product, even though the method is comparatively longer than the extrusion technique. Research on the incorporation of fillers in resin is increasing in recent years, and one of the main approaches is cellulose-based fillers. The purpose of the incorporation is to improve the mechanical properties and thermal stability of the printed product. The compilation of the recent activity on the addition of cellulose-based polymer in photopolymeric resins is simplified in Table 4.

Cellulose that possesses hydrophilic properties can be homogenized effectively in the polymer matrix that is hydrophilic. For example, the addition of $\mathrm{CNC}$ in the photoinitiation of polyethylene diacrylate (PEGDA) improved the mechanical and thermal properties of the printed product [107]. Due to the hydrophilicity of CNC and PEGDA, the interlayer adhesion improved with the addition of $0.3 \% \mathrm{CNC}$, thus enhancing the tensile strength by $100 \%$ compared to the neat PEGDA. 
Similar to FDM, surface grafting of cellulose has to be done to incorporate cellulose in hydrophobic polymer matrix. Incorporation of CNF that is surface grafted with reduced graphene oxide (rGO) and printed in SLA printer was able to enhance the tensile stress by $37 \%$ and nanoindentation hardness by $129 \%$ compared to neat polyurethane resin [17]. Morphological analysis showed the grafting of rGO in CNF nullified the hydrophilicity of CNF and improved the dispersion of CNF in the polyurethane matrix, whereas the incorporation of non-grafted CNF in polyurethane matrix displayed voids on the printed surface due to surface incompatibility of hydrophilic CNF and hydrophobic polyurethane. Lignin-coated CNC can also be considered as it was able to enhance the mechanical strength and thermal stability of photocurable methacrylate resin [108]. The addition of $0.1 \%$ lignin-coated CNC was sufficient enough to enhance the tensile strength and modulus with further increment of filler reduced the mechanical properties. A post-curing step of heating at $120^{\circ} \mathrm{C}$ can be considered, as it further enhanced the mechanical properties due to the esterification of the resin matrix and lignin-coated CNC.

The recent development for cellulose based printing using VP technology is the development of methacrylated carboxymethyl cellulose bioink for biomedical application, as shown in Figure 5 [109]. CMC modified using methacrylate anhydride and added with photoinitiators to print complex geometries that possess high mechanical properties showed advancement in the development of VP inks, which are suitable for tissue engineering and, most importantly, biodegradable.
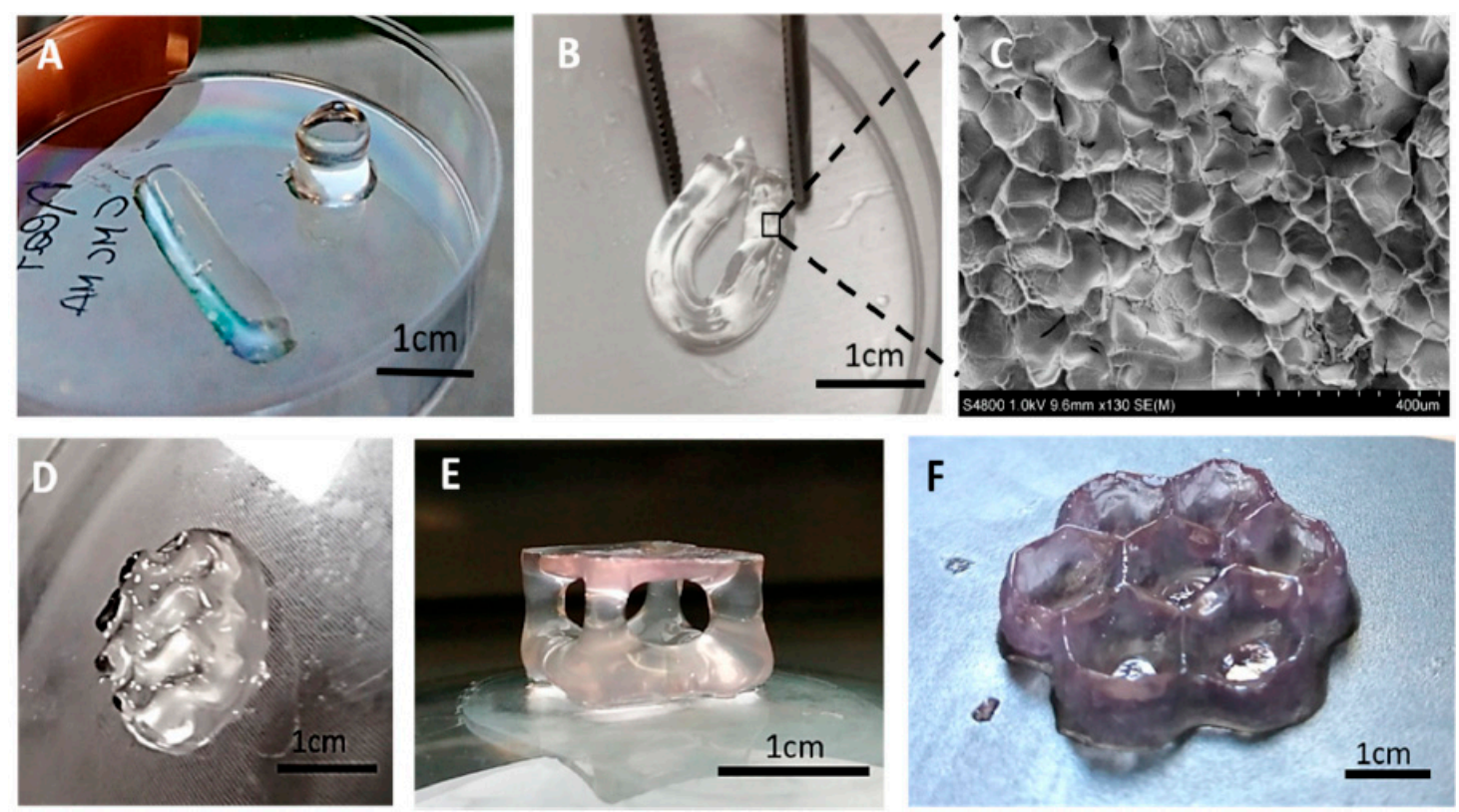

Figure 5. 3D-printed M-CMC hydrogels: (A) Simple cylinders and parallelepipeds (solvent: water); (B) The hydrogel exhibited good flexibility and handleability; (C) SEM analysis performed on the freeze-dried hydrogel; and 3D objects printed from water (D) and culture medium solution (E,F) [109].

In addition, silver nanoparticles loaded with CNC were dispersed in polymethyl metharcylate to investigate the reinforcement in terms of mechanical and antimicrobial activities [110]. CNC grafted with dopamine and loaded in silver nanoparticles, as shown in Figure 6, improved the dispersion of silver nanoparticle-CNC composites in the polymer resin, as observed in its morphology. Incorporation of $0.1 \mathrm{wt} . \%$ of silver nanoparticle-CNC in the resin enhanced the mechanical strength of the composite by $12 \%$ as compared to neat resin. The antimicrobial characteristics of the composite was enhanced significantly by the incorporation of grafted $\mathrm{CNC}$ with silver nanoparticles compared to neat resin. 
Table 4. The compatibility of cellulose-based biopolymer as a filler in photopolymeric resins.

\begin{tabular}{|c|c|c|c|c|c|}
\hline Cellulose Composition & 3D Printer & Printing Parameter & $\begin{array}{l}\text { Solidification } \\
\text { Method }\end{array}$ & $\begin{array}{l}\text { Potential } \\
\text { Application }\end{array}$ & Ref. \\
\hline $\begin{array}{l}\text { Polyurethane aryclate, } \\
\text { CNF-rGO, CNF-PEG }\end{array}$ & $\begin{array}{c}\text { Wanhao } \\
\text { Duplicator D7 } \\
\text { Plus }\end{array}$ & $\begin{array}{l}\text { UV light of wavelength } \\
405 \mathrm{~nm}\end{array}$ & UV curing & Bio based resin & [17] \\
\hline $\begin{array}{c}\text { Polymethyl methacrylate } \\
\text { (PMMA), CNC-Silver } \\
\text { Nanoparticles } \\
\text { (CNC-AgNPs) }\end{array}$ & Envision TEC & $\begin{array}{l}\text { Layer thickness } 100 \mu \mathrm{m} \text {, } \\
4.4 \text { s exposure time, } \mathrm{UV} \\
\text { intensity } 2500 \mu \mathrm{m} / \mathrm{cm}^{2}\end{array}$ & UV curing & $\begin{array}{l}\text { Dental } \\
\text { restoration } \\
\text { material }\end{array}$ & [110] \\
\hline $\mathrm{CNC}$, methacrylate resin & Form 1+ & N/A & $\begin{array}{l}\text { Photocuring } \\
\text { and heating }\end{array}$ & $\begin{array}{l}\text { Electronic, } \\
\text { engineering } \\
\text { and tissue } \\
\text { engineering }\end{array}$ & [111] \\
\hline $\begin{array}{l}\text { Ethyl cellulose } \\
\text { macromonomerm } \\
\text { resin-based monomer }\end{array}$ & $\begin{array}{l}\text { Creality, LD } \\
\text { 001, }\end{array}$ & N/A & Photocuring & $\begin{array}{l}\text { Flexible } \\
\text { electronic } \\
\text { materials }\end{array}$ & [112] \\
\hline $\begin{array}{c}\text { CNC, PEGDA, } \\
\text { 1,3-diglycerolate } \\
\text { diacrylate (DiGlyDA) }\end{array}$ & DLP 3D printer & $\begin{array}{l}\text { Layer thickness } 100 \mu \mathrm{m} \text {, } \\
4.0 \text { s exposure time, } \mathrm{UV} \\
\text { intensity } 18 \mathrm{~mW} / \mathrm{cm}^{2}\end{array}$ & UV curing & $\begin{array}{l}\text { Biomedical } \\
\text { application }\end{array}$ & [113] \\
\hline
\end{tabular}

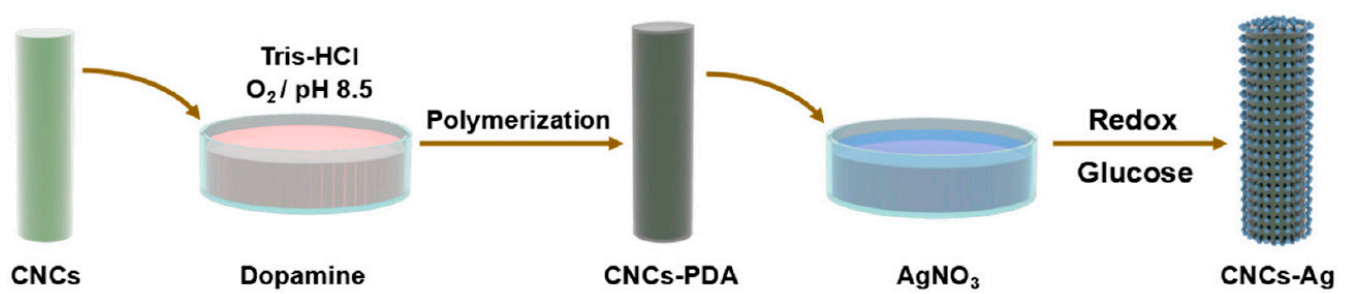

Figure 6. Synthetic route of nanocrystalline cellulose-silver (CNC-Ag) composite [110].

\subsection{Liquid Deposition Modeling}

As cellulose solution has the shear-thinning property, the solution can be readily used for ME printing technique, which is usually known as direct ink writing for liquid deposition modeling (LDM). The product printed with liquid cellulose should retain the shape after printing; thus, viscosity is essential, which is directly related to the concentration of cellulose and the shear rate applied. High mechanical strength of the printed part is vital to maintain the printed shape; therefore, increasing the concentration of cellulose can improve strength and reduce shrinkage, which consequently reduces the accuracy and smoothness of the printed part.

The design flow chart of any bioink is well-demonstrated in this study, where the prepared solution must initially satisfy the rheological behavior [114]. The concentration can be altered if the parameter does not satisfy the rheological requirement. The extrusion pressure and printing speed will be altered to obtain optimum printing line width. Cross-linking is studied to produce a solidified product and the agent can be varied to obtain a stable medium. Moreover, the sterility of the bioink is studied with cell proliferation to successfully produce bioink that is suitable for biomedical applications. The models can be altered to suit the application and desired results.

Cellulose solution with smaller particles can be extruded through small-sized nozzles and maintained in the desired shape after printing. One of the earliest demonstrations of cellulose printing was the dissolution of cellulose in ionic solution, 1-ethyl-3-methylimidazolium acetate, and the results show that cellulose could be printed at low concentrations with a micro-sized dispensing nozzle passing through six layers [115]. The coagulation after printing obtained using a non-ionic solvent was able to regenerate the cellulose, thus acquiring a stable structure. 
The other viable option for cellulose liquid printing is the dissolution of CA in acetone prior to printing and solidification of the printed part through evaporation [116]. The dissolution of the process enhanced the rheology of printing solution and the extrudability with the printing is accurately observed through the complex product of eyeglass frames and a rose. The hydroxyl bonds of cellulose can be restored with the removal of acetyl groups from the acetone. Surprisingly, these printed products had a tensile strength of $45 \mathrm{MPa}$, which is comparable to commercial polymers such as PLA and ABS, making it a favorable option for the commercialization of biodegradable material or cellulose-based printing.

Cellulose can also be printed readily without dissolution by the condition of optimum rheology and particle size to have smooth extrusion. $\mathrm{CNC}$ gels at different concentrations ranging from 11.8 to $30 \mathrm{wt} . \%$ in water were printed in an ordered structure with controllable porosity, printing resolution, and inner pore structure [117]. The shear-thinning behavior of nanocellulose allowed smooth extrusion, and high viscosity allowed a stable structure to be printed. The bowl structure printed using $20 \mathrm{wt}$. \% CNC with different nozzle inner diameters showed different smoothness and shape deviations. The printing time required was compensated to achieve better print quality and smoothness as the difference was almost six times longer when the printing resolution was improved from 500 to $200 \mu \mathrm{m}$. The mechanical properties of the CNC aerogel were enhanced by the cross-linking with polyamide-epichlorohydrin, and an increment of Young's modulus by $27 \%$ was observed. The potential of this printing method can be further studied as the method will be beneficial for tissue engineering applications with dual pore structures.

Other than CNC, CMC powder dissolution in water at the concentration of $45 \mathrm{wt} . \%$ and dispensed in a 30- $\mu \mathrm{m}$ nozzle successfully printed five square layers with stacking ability, and the total product height was $43 \mu \mathrm{m}$ [118]. A low concentration of CMC printing resulted in ink smearing, and the line width printed was bigger than the nozzle, which affected the accuracy and smoothness of the printed products. The printing profile results in this study can be used for the fabrication of CMC products to be applied in tissue engineering. Further improvement of printing parameters needs to be conducted to enhance the resolution of the printed products.

Furthermore, CNF suspension can also be printed at a lower concentration of $0.91 \mathrm{wt}$. \% on a heated bed by controlling the extrusion pressure and printing speed [79]. CNF with the shear-thinning property extruded at the pressure of $172 \mathrm{kPa}$ had an optimum flow rate of CNF printing. The variation of heated bed temperature also influenced the printed line width due to water evaporation, and a gel-like structure was formed. The hardness and tensile strength of the CNF printed product were 590 and $72.6 \mathrm{MPa}$, respectively, which can be adopted for biomedical engineering applications, as it managed to print $\mathrm{CNF}$ with mechanical properties comparable to CNF films in a much shorter time.

Cellulose composited with different materials is also being studied intensively as cellulose provides the strength and shape fidelity while the fillers are used to have certain functionalities. Figure 7 shows that a study proved that $4 \%$ sodium alginate with $4 \%$ CMC has good extrudability and shape fidelity after printing as well as that a lower concentration of CMC did not have good printability. The printed sample was used in cell proliferation studies and determined to have comparable viable cells with alginate after 23 days, proving that CMC improves alginate printing without affecting alginate properties [119].

Besides that, CNC with xyloglucan at a ratio of 100:1 $(<4 \mathrm{wt} \%)$ can be printed using direct cryowriting (DCW) on a build plate that has freezing capability to build solid structures, as shown in Figure 8 [120]. Xyloglucan acts as a binder that enhances the extrudability of CNC, thus providing better shape fidelity of the printed structure. The impressive part of this formulation and cryoprinting method that can be adopted for cellulose-based printing is that a complex vase structure can be printed without support. 


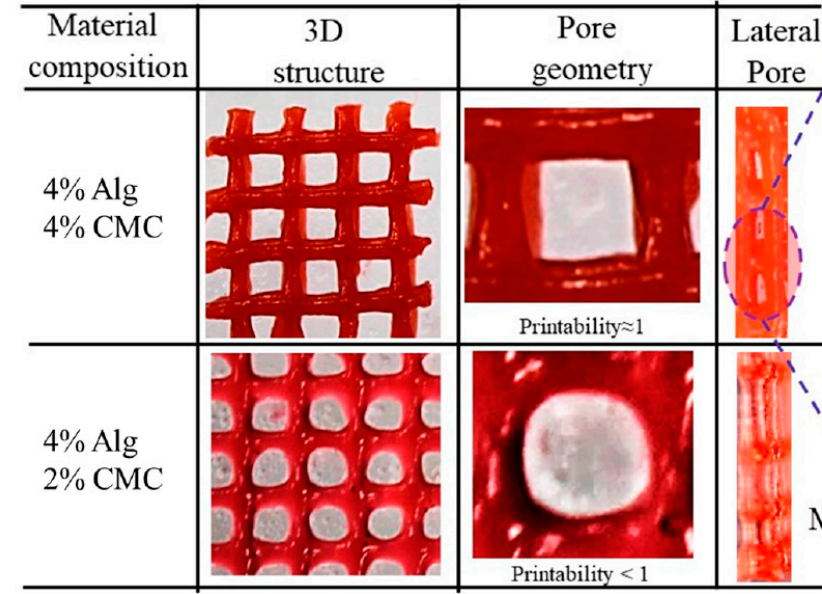

(a)

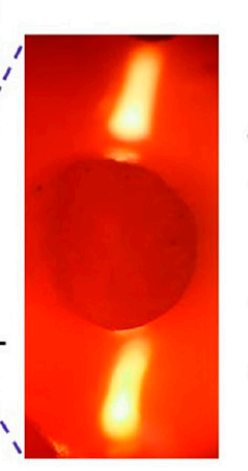

Microscopic view of lateral pore

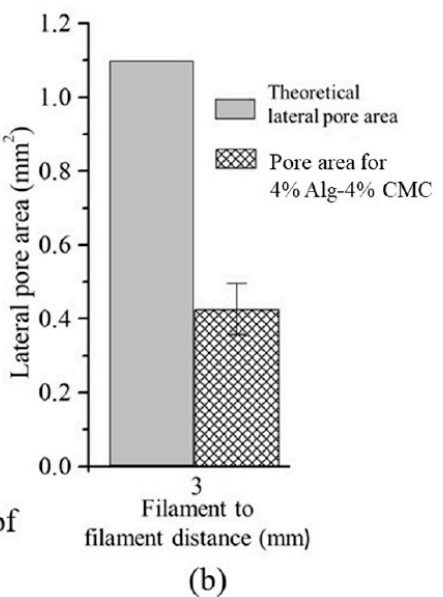

(b)

Figure 7. (a) Qualitative; and (b) quantitative tests for lateral pores [119].
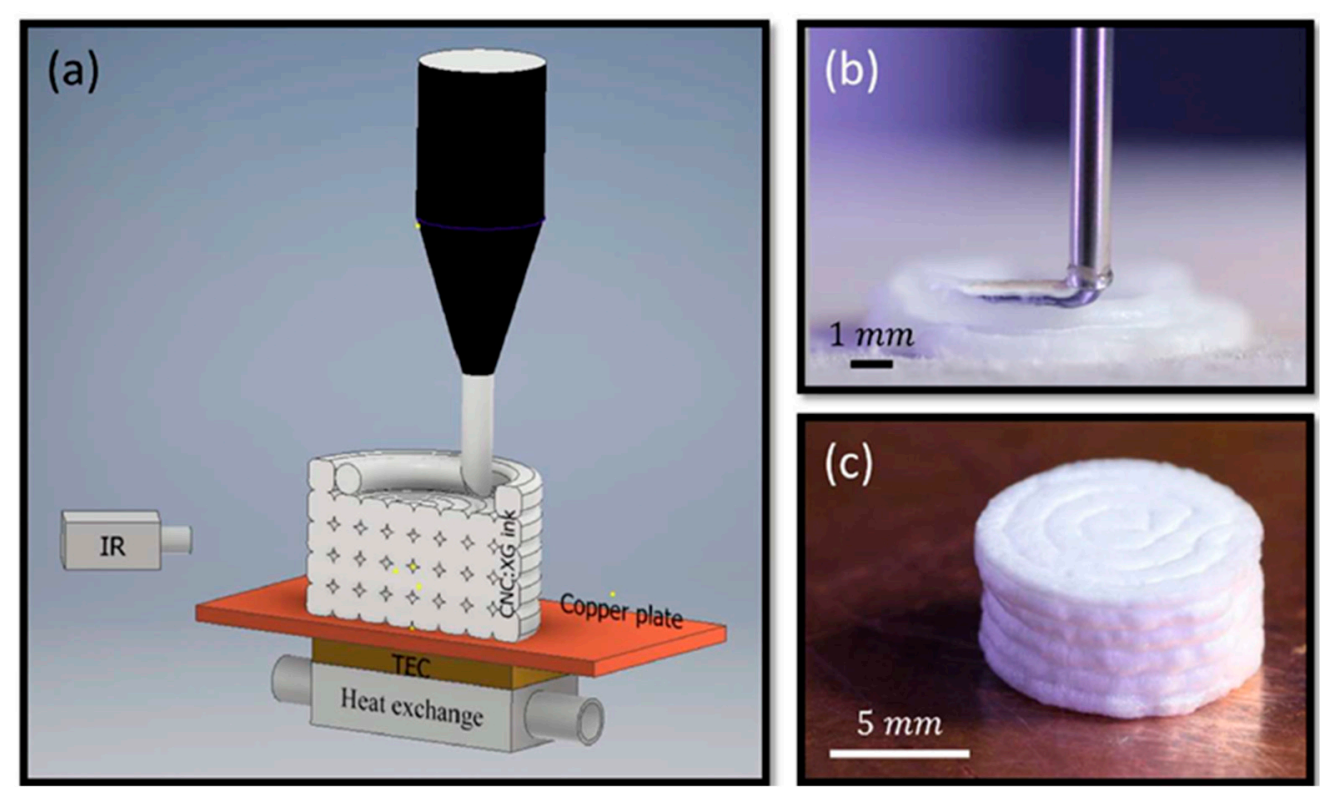

Figure 8. (a) Schematic illustration of the DCW setup; (b) photograph of the DCW printing process; and (c) photograph of the final aerogel [120].

The LDM technique of commercial PLA with CA at different ratios was applied to determine the suitable viscosity for extrusion and the ability to maintain the shape fidelity after printing. Overall, $70 \%$ PLA and 30\% CA were determined as the optimum combination, as the rheological behavior was found to have shear-thinning properties desirable for smooth extrusion. The increase of CA showed a detrimental effect on the extrusion, as the repulsive force present between CA and PLA reduced the storage and loss modulus. The optimum printing parameters were determined to be a print speed of $16 \mathrm{~mm} / \mathrm{s}$ and extrusion pressure of $15 \mathrm{psi}$, which resulted in the printed line width of $250 \mu \mathrm{m}$ [121].

$\mathrm{BC}$ with alginate printing has been done research immensely for applications such as fabrication of tissue scaffolds, antimicrobial composite with different additives such as copper and nanoclay [122,123]. It was found that $70 \mathrm{wt} . \% \mathrm{BC}$ and $30 \% \mathrm{wt} . \%$ alginate were suitable for printing due to the shearthinning property and ability to have a dimensionally accurate structure after cross-linking with calcium chloride [122]. The incorporation of BC helped to maintain the shape fidelity, as pure alginate printing shrank upon cross-linking. Table 5 reviews the studies done on liquid deposition of cellulose-based materials using various printing techniques and materials. 
Table 5. Review of cellulose matrix as 3D printing hydrogel using LDM technique.

\begin{tabular}{|c|c|c|c|c|c|}
\hline Cellulose Composition & 3D Printer & Printing Parameter & $\begin{array}{l}\text { Solidification } \\
\text { Method }\end{array}$ & $\begin{array}{l}\text { Potential } \\
\text { Application }\end{array}$ & Ref. \\
\hline $\begin{array}{l}\text { Dialdehyde } \mathrm{CNC} \text {, } \\
\text { gelatin }\end{array}$ & Bio-Architect & $\begin{array}{l}\text { Nozzle } 0.21 \mathrm{~mm} \text {, Extrusion } \\
\text { pressure } 100-250 \mathrm{kPa} \text {, } \\
\text { Print speed } 10-40 \mathrm{~mm} / \mathrm{s}\end{array}$ & $\begin{array}{l}\text { Crosslinking } \\
\text { with } \mathrm{Ca}^{2+}\end{array}$ & $\begin{array}{c}\text { Tissue } \\
\text { engineering }\end{array}$ & [124] \\
\hline CNF, Alginate & $\begin{array}{l}\text { Regemat3D } \\
\text { Designer }\end{array}$ & $\begin{array}{l}\text { Nozzle } 0.58 \mathrm{~mm} \text {, Flow } \\
\text { speed } 3.0 \mathrm{~mm} / \mathrm{s}\end{array}$ & $\begin{array}{l}\text { Crosslinking } \\
\text { with } \mathrm{CaCl}_{2}\end{array}$ & $\begin{array}{c}\text { Tissue } \\
\text { engineering }\end{array}$ & [125] \\
\hline $\begin{array}{l}\text { Bacterial CNF, silk } \\
\text { fibroin (SF)/gelatin } \\
\text { composite }\end{array}$ & 3D Bioplotter & $\begin{array}{l}\text { Nozzle } 0.41 \mathrm{~mm} \text {, Extrusion } \\
\text { pressure } 1-2 \text { bar, Print } \\
\text { speed } 3.0\end{array}$ & $\begin{array}{l}\text { Crosslinking } \\
\text { with genipin }\end{array}$ & $\begin{array}{l}\text { Biomedical } \\
\text { applications }\end{array}$ & [126] \\
\hline $\begin{array}{c}\mathrm{CNF}, \\
\text { xylan-tyramine }\end{array}$ & $\begin{array}{l}\text { 3D bioprinter, } \\
\text { RegenHU, } \\
\text { Switzerland }\end{array}$ & $\begin{array}{l}\text { Nozzle } 0.42 \mathrm{~mm} \text {, print } \\
\text { speed } 40 \mathrm{~mm} / \mathrm{s} \text {, layer } \\
\text { height } 0.4 \mathrm{~mm}\end{array}$ & $\begin{array}{l}\text { Crosslinking } \\
\text { with } \mathrm{H}_{2} \mathrm{O}_{2}\end{array}$ & $\begin{array}{l}\text { Clothes, } \\
\text { packaging, health } \\
\text { care products, } \\
\text { furniture }\end{array}$ & [127] \\
\hline $\mathrm{CNF}, \mathrm{CMC}$ & Bioscaffolder 3.1 & $\begin{array}{c}\text { Nozzle } 0.25 \mathrm{~mm} \text {, Extrusion } \\
\text { pressure } 260 \mathrm{kPa} \text {, print } \\
\text { speed } 15 \mathrm{~mm} / \mathrm{s}\end{array}$ & $\begin{array}{l}\text { Crosslinking } \\
\text { with } \\
\text { dehyrothermal } \\
\text { treatment } \\
\text { (DHT) }\end{array}$ & $\begin{array}{l}\text { Bone tissue } \\
\text { engineering }\end{array}$ & [128] \\
\hline CNF, carbon nanotubes, & Fisnar F4200n, & $\begin{array}{l}\text { Nozzle pressure } 345 \mathrm{kPa} \text {, } \\
\text { Print speed } 10 \mathrm{~mm} / \mathrm{s}\end{array}$ & $\begin{array}{c}\text { Solvent } \\
\text { exchange with } \\
\text { ethanol }\end{array}$ & $\begin{array}{l}\text { Biomedical } \\
\text { application }\end{array}$ & [129] \\
\hline $\begin{array}{l}\text { CNF, 2,2,6,6-Tetramethyl- } \\
\text { 1-piperidinyloxy }\end{array}$ & $\begin{array}{l}\text { Custom built } \\
\text { LDM printer }\end{array}$ & N/A & Oven treatment & $\begin{array}{l}\text { Oil-in-water } \\
\text { separation, } \\
\text { electronic related } \\
\text { application }\end{array}$ & [130] \\
\hline CNC (20 wt $\%)$ & $\begin{array}{l}\text { Custom built } \\
\text { multi-material- } \\
\text { multi-method 3D } \\
\text { printer }\end{array}$ & $\begin{array}{l}\text { Nozzle } 0.4 \mathrm{~mm} \text { Extrusion } \\
\text { pressure } \mathrm{kPa} \text {, Print speed } \\
\qquad 0 \mathrm{~mm} / \mathrm{s}\end{array}$ & None & $\begin{array}{l}\text { Support during } \\
\text { 3D printing }\end{array}$ & [131] \\
\hline $\begin{array}{c}\mathrm{CNC} \text {, sodium alginate, } \\
\text { gelatin }\end{array}$ & $\begin{array}{l}\text { Ultimaker with } \\
\text { Discov3ry } \\
\text { Complete }\end{array}$ & $\begin{array}{l}\text { Print speed } 30 \mathrm{~mm} / \mathrm{s}, \\
\text { printing temperature } 26^{\circ} \mathrm{C}\end{array}$ & $\begin{array}{l}\text { Crosslinking } \\
\text { with } \mathrm{CaCl}_{2}\end{array}$ & $\begin{array}{l}\text { Cartilage } \\
\text { regeneration } \\
\text { application }\end{array}$ & [132] \\
\hline $\begin{array}{c}\text { CMC, silver nanowire, } \\
\text { lithium iron } \\
\text { phosphate/lithium } \\
\text { titanate }\end{array}$ & $\begin{array}{l}\text { Delta FDM 3D } \\
\text { printer integrated } \\
\text { with Discov3ry } \\
\text { Extruder }\end{array}$ & $\begin{array}{c}\text { Nozzle } 0.84-1.54 \mathrm{~mm} \text {, } \\
\text { print speed } 0.7-1.2 \mathrm{~mm} / \mathrm{s} \text {, } \\
\text { Extrusion flow rate } \\
0.0002-0.00083 \mathrm{~mL} / \mathrm{s}\end{array}$ & Drying & $\begin{array}{c}\text { Conductive } \\
\text { nanocomposites }\end{array}$ & [133] \\
\hline $\mathrm{CNC}$ & ABL 900010, & $\begin{array}{c}\text { Nozzle } 0.41 \mathrm{~mm} \text {, extrusion } \\
\text { pressure } 200-400 \mathrm{kPa} \text {, } \\
\text { print speed } 10-20 \mathrm{~mm} / \mathrm{s}\end{array}$ & Drying & $\begin{array}{c}\text { Cellular } \\
\text { architectures }\end{array}$ & [134] \\
\hline $\begin{array}{l}\text { CNC, 2-hydroxyethyl } \\
\text { methacrylate monomer, } \\
\text { polyether urethane } \\
\text { acrylate oligomer, } \\
\text { photoinitiator }\end{array}$ & $\begin{array}{l}\text { 3D Discovery, } \\
\text { RegenHU Ltd., } \\
\text { Switzerland }\end{array}$ & $\begin{array}{c}\text { Nozzle } 0.41 \mathrm{~mm} \text {, extrusion } \\
\text { pressure } 300-400 \mathrm{kPa} \\
\text { print speed } 10 \mathrm{~mm} / \mathrm{s}\end{array}$ & Photocuring & $\begin{array}{c}\text { Cellular } \\
\text { architectures }\end{array}$ & [134] \\
\hline $\begin{array}{c}\text { Cellulose, } \\
\text { N-methylmorpholine- } \\
\text { N-oxide (NMMO) }\end{array}$ & 3D Bioplotter & Printing temperature $70^{\circ} \mathrm{C}$ & $\begin{array}{l}\text { Coagulation in } \\
\text { water (NMMO } \\
\text { removal), } \\
\text { freeze drying }\end{array}$ & $\begin{array}{c}\text { Tissue } \\
\text { engineering }\end{array}$ & [135] \\
\hline Cellulose fibers, CMC & $\begin{array}{l}\text { Prusa i3 with } \\
\text { WASP extruder }\end{array}$ & $\begin{array}{l}\text { Nozzle } 0.7 \mathrm{~mm} \text {, print } \\
\text { speed } 10-20 \mathrm{~mm} / \mathrm{s}\end{array}$ & $\begin{array}{l}\text { Solvent } \\
\text { exchange, } \\
\text { Drying }\end{array}$ & $\begin{array}{l}\text { Lightweight 3D } \\
\text { printed material }\end{array}$ & [136] \\
\hline $\begin{array}{c}\text { CNF, carbon nanotubes, } \\
\mathrm{NaOH}\end{array}$ & $\begin{array}{l}\text { RegenHU 3D } \\
\text { Discov3ry }\end{array}$ & $\begin{array}{l}\text { Nozzle } 0.3 \mathrm{~mm} \text {, Extrusion } \\
\text { pressure } 65 \mathrm{kPA} \text {, Print } \\
\text { speed } 10 \mathrm{~mm} / \mathrm{s}\end{array}$ & $\begin{array}{l}\text { Drying } \\
\text { (ambient } \\
\text { condition) }\end{array}$ & $\begin{array}{l}\text { Neural tissue } \\
\text { engineering }\end{array}$ & [137] \\
\hline
\end{tabular}




\subsection{Applications}

Instead of using synthetic polymers as materials for 3D printing, cellulose-based polymers are effective as the polymers are derived from natural resources, which can reduce the impact of fossil fuel depletion. Cellulose has several distinct properties, such as biocompatibility, biodegradability, surface grafting, and biodegradability, which are useful for many applications, such as medical, textile, tissue engineering, pharmaceutical, and electronic applications. The utilization of 3D-printed cellulose materials for various applications is reviewed in the following sections.

\subsubsection{Biomedical Engineering}

3D printing technology has been extensively used in medical applications, especially in drug delivery, tissue engineering, and wound healing. A recent study of 3D-printed nanocellulose double laminated with calcium carbonate was found to have controlled drug delivery of anticancer drug over the duration of $24 \mathrm{~h}$, which is a good finding to reduce the side effect of drug burst release [138]. The drug release rate of the double laminated composite was up to $89.88 \% \pm 0.37 \%$, comparable to the drug release rate of porous calcium carbonate up to $91.37 \% \pm 0.16 \%$, thus achieving the objective of using nanocellulose as a drug carrier in a solution that has similar properties to the colon.

Carbamazepine drugs usually used to treat colonic seizure disorder were dispersed in ethyl cellulose and hydroxypropyl cellulose, and then printed as tablets to investigate the controlled drug delivery properties [139]. 3D-printed tablets showed a more controlled release of drugs compared to the $3 \mathrm{D}$ filaments containing carbamazepine, due to the high surface area exposure of the filaments, and the solution could penetrate the filaments deeper. Ethyl cellulose with a ratio of 2:1 to hydroxypropyl cellulose showed a zero-order controlled drug release profile for a period of $24 \mathrm{~h}$; thus, this method can be studied for controlled drug release for some low dose drug treatments.

The optimization of the viscosity of polyurethane with hydrophilic properties was carried out for 3D printing by the addition of nanocellulose and triethylamine. The cell growth was better in the polyurethane/nanocellulose composite; thus, the condition is favorable for tissue engineering with the features of better mechanical properties and structural ability [140]. The viable cell rate in polyurethane/nanocellulose composite after a fortnight was $537 \%$, while that of polyurethane/ polyethylene oxide composite was about $300 \%$ owing to better cell attachment to the interior and surface of the fibers.

In a previous study, $95 \%$ PCL as a biodegradable polymer was added to $5 \% \mathrm{BC}$, and the mixture was printed to evaluate the extrudability and cell growth on the specimens [141]. After $72 \mathrm{~h}$, the cell growth was observed and the viable cells were higher by $155 \%$ compared to the control, and the PCL-BC printed scaffold enhanced the cell proliferation through the 3D printing method. 3D printing is essential as the process can produce a proper scaffold and integrated structure that affects cell growth and alignment. The printing of CNF and alginate with the cross-linking of $\mathrm{CaCl}_{2}$ at different concentrations was studied to determine the best printing condition without shrinkage [142]. Cross-linking with a higher concentration of $\mathrm{CaCl}_{2}$ reduced the water absorption capacity of the sample, and also reduced the shrinkage of $\mathrm{CNF} /$ alginate composite. This study shows a positive finding that can be used in wound dressing application at the alginate concentration of $20 \mathrm{wt}$. \% relative to CNF due to excellent water absorption and better structural ability.

The wound healing property of 3D-printed BC with chondroitin sulfate and hyaluronic acid was evaluated on a patient diagnosed with diabetic foot wound [143]. After applying the dressing on alternate days for one month of treatment, the study showed a positive result based on the reduction of the wound area and recovery at the surrounding area. Four months of treatment showed complete healing with minimal scar that can be concealed over time. This is a promising method for diabetic wound healing applications as BC is a promising material for cell growth. CA of $25 \mathrm{wt}$. \% with a rheological modifier (i.e., glycerol) could be printed at a very high resolution of 99-608 $\mu \mathrm{m}$ with the optimization of extrusion pressure, printing speed, and extrusion nozzle diameter [144]. This approach can be used in the formulation of medical applications that require a high-resolution printed product. 
CA has good tissue engineering properties with high mechanical properties and the material is able to imitate the cell matrix for cell proliferation studies.

Cellulose-based 3D printing materials are emerging in biomedical applications, especially in controlled drug delivery, wound healing, and cell growth. In vivo studies are continuously conducted to overcome obstacles and further improve cellulose-based 3D printing materials. There is a small gap for this printing technique to be readily used for patients, but it will require approval for application on humans.

\subsubsection{Electronic Engineering Applications}

Artificial intelligence robots are developing rapidly in recent years to ease human-to-machine interaction, hence driving the development of electronic sensors for the detection of signals from humans and processing the signals into the language that a machine can interpret. Cellulose-based $3 \mathrm{D}$ printing materials are important in the development of electrical engineering applications by the integration with certain metals to acquire stronger mechanical properties and obtain the desired functions. 3D printing will assist in the manufacturing of complex objects that are difficult to be printed through traditional manufacturing processes.

A humidity sensor was 3D printed with the composite of CA and aluminum to detect the humidity of sweat in a contactless manner [145]. The sensor was printed with a programmable response that could bend at $45^{\circ} \mathrm{C}$ and would connect the circuit in the presence of a finger, which is the stimulus of humidity to trigger the alarm. This is a novel method that can be used in health monitoring and human-machine interaction applications.

The 3D printing of silver nanowire as a conductive material and CMC as a rheological modifier was performed to produce a lithium battery with an anode, a cathode, and a separator [133]. Increased conductivity was observed with the increasing concentration of silver nanowire, and the solid content of $\mathrm{CMC} /$ silver nanowire was fixed at $25 \mathrm{wt}$. \% to obtain the desired viscosity for printing. The voltage of the cellulose-based printed battery was determined to be $1.8 \mathrm{~V}$, which agrees with commercial batteries and proves that cellulose-based electronics can become the next generation material. The electrical conductivity of $\mathrm{CNF}$ composite with the addition of lithium produced using 3D printing technology was evaluated [146]. CNF is essential in maintaining the structure after printing due to its high mechanical properties, and the shear-thinning properties assist in the smooth extrusion of the battery anode and cathode. The 3D-printed lithium-based anode and cathode with CNF exhibited a high specific capacity with the advantage of various designs through $3 \mathrm{D}$ printing.

The study of 3D-printed CNF/alginate-based hydrogel cross-linked with calcium ions was conducted to evaluate the electrical conductivity for organic electronics [147]. CNF/alginate hydrogel functionalized with poly(3,4-ethylenedioxythiophene) displayed high electrical conductivity and could store electrical charge. As cellulose is able to alter its form with water presence due to its hygroscopic nature, the electrical conductivity changes with respect to humidity, thus making cellulose suitable to be used as a humidity sensor.

$\mathrm{CNF} /$ silver nanowire composite demonstrated better electrical conductivity compared to $\mathrm{CNC} /$ silver nanowire in the production of a biocompatible sensor [148]. $\mathrm{CNF} /$ silver nanowire composite demonstrated better electrical conductivity compared to $\mathrm{CNC} /$ silver nanowire in the production of a biocompatible sensor. 3D-printed cellulose-based composites are being investigated thoroughly for the printing of electrically conductive materials due to cellulose properties that can maintain the shape fidelity and change the structure based on the surrounding conditions.

\subsubsection{Other Applications}

3D printing of food applications using cellulose-based materials has grown remarkably in recent years with the development of bioprinters with multi-nozzles. Research has been continuously done on the rheology of the material in order to obtain printable paste solutions because $3 \mathrm{D}$ printing can be used in food applications to produce food with the desired shape and amount. CNF-based food 
printing was done with the homogenization of milk powder and starch, as a small concentration of CNF helps to maintain the printed food structure [149]. Cellulose powder was bound with xanthan gum in a study where sample consisting of 10 layers were printed [150]. Optimization can be done on the viscosity and heating parameters to create more complex structures to be used in food-based products using BJ printing technique.

As biomaterials are increasingly used in textile and fashion industries to replace petroleum-based products, 3D printing of cellulose-based products can be studied to customize products based on the demand and to create stronger products. CA consisting of a linear structure and acetoxypropyl cellulose was printed on woven cotton-based fabrics to study the viability of cellulose-based materials for textile applications [151]. CA alignment with cellulose molecules on the substrate resulted in better adsorption and interfacial adhesion compared to acetoxypropyl cellulose but both cellulose based materials can be studied for development of all cellulose-based textile applications. CNF plasticized with glycerol was studied to be used as a coating on woven cotton fabrics and found that CNF coating reduces the amount of fabric pigment needed while maintaining the mechanical properties [152]. $\mathrm{CNF}$ coating on fabrics can be fabrication of electronic textiles for medical and other applications that do not require washing.

Neat cellulosic nanomaterials demonstrated excellent oxygen barrier properties compared to cellulose composite materials, which highlights the potential of airtight packaging for food and pharmaceutical applications [153]. The application of high-resolution CNC ink can be further studied for packaging and to satisfy customers' needs on the desired packaging shape using LDM [117].

\section{Cellulose-Based Polymers in 4D Printing Technology}

\subsection{Cellulose-Based Responsive Materials}

Cellulose-based materials possess remarkable properties as discussed earlier and the addition of smart polymers allows for better applications in some industries. The response of these materials toward a stimulus is promising, coupled with sustainable and biodegradable nature, which can diversify the range of applications of the materials. New applications in biomedical engineering have led to increased attention on the extensive development of cellulose-based smart materials. In this section, different types of stimuli of recently developed cellulose-based smart materials are reviewed.

\subsubsection{Heat Responsive}

$\mathrm{CNC}$ and polyurethane composite produced through direct melt mixing are thermally sensitive and exhibit shape-memory properties [154]. The addition of phosphorylated CNC improved stiffness and shape-memory properties compared to neat polyurethane. The flat sample was heated to $70{ }^{\circ} \mathrm{C}$ and the temporary shape was fixed as a spiral part by twisting around the metal rod. The flat shape could be recovered in $20 \mathrm{~s}$ and after placing the sample in an oil bath at $70^{\circ} \mathrm{C}$. The addition of $\mathrm{CNC}$ improved the shape fixity of the composite by bridging the crystalline domains present in the composites. Hence, $\mathrm{CNC}$ and polyurethane composite have a huge potential to be used in biomedical applications.

Surface grafting CNC with lower critical solution temperature (LCST) polymer within polyvinyl acetate matrix produced good mechanical and shape-memory properties [155]. The stiffness of the composite could be reversed when immersed in hot water due to the collapse of the LCST polymer, and the properties could be reversed again by immersing in cold water. Hence, the CNC-polymer composite can be altered to be stiffer at body temperature, and this feature is suitable to be used as reinforcing implants in biomedical engineering applications. 


\subsubsection{Moisture Responsive}

As cellulose is hydrophilic in nature, many cellulose-based materials responsive to water have been developed and applied in various applications. Cellulose nanofibrils (CNF) were utilized to produce thin films with the potential to be used as biometric actuators. Water vapor can be used to control the actuation of CNF that reacts to the difference of humidity level [156].

The produced thin films can bend upon contact with humid layers, which is attributed to the increase in the volume of the hydrated layer. The uneven increase in the volume of the opposite side of the films leads to the bending motion, and similar findings have also been observed in other studies [157,158]. CNC-based films have also been used as humidity sensors with $99.8 \%$ colorimetric response value in the application of intelligent packaging for moisture-sensitive products [159]. CNC-based films have also been used as humidity sensors with $99.8 \%$ colorimetric response value in the application of intelligent packaging for moisture-sensitive products.

\subsubsection{Light Responsive}

Photo-responsive cellulose-based materials exhibit changes in properties when exposed to light. A sun exposure sensor was developed by printing a mixture of titanium dioxide, polyvinyl propylene, and food dye on a paper. The titanium dioxide particles act as a photocatalyst. When exposed to the sun, the titanium dioxide particles degraded the food dye present in the paper, hence resulting in discoloration. Further calibration was conducted to match the UV exposure time for several different skin types [160].

Photochromic molecules were dissolved in ionic liquid and coated on cellulose fibers through hydrogen bonding, and the light-responsive properties were investigated [161]. The prepared paper demonstrated reversible and rapid photo-responsive color changing behavior when irradiated with UV and visible light. This allows potential applications in photowritable and photoerasable displays and UV sensors.

Photo-responsive cellulose nanoparticle coating was developed through a combination of donor-acceptor Stenhouse adducts and cellulose stearic acid ester. The developed composite could be switched reversibly between hydrophobic and hydrophilic properties through exposure to visible light. The coating can be applied onto papers and allow the production of paper-based fluid timers [162]. The incorporation of CNC and 2-bromoisobuuturyl bromide into 6-[4-(4-methoxyphenyl-azo) phenoxy] hexyl methacrylate produced a photo-responsive composite that changes in color through the irradiation to light with the wavelength of $350 \mathrm{~nm}$ [163].

\subsubsection{Magnetic Responsive}

Magnetically-responsive cellulose-based materials can be produced by the deposition of magnetite nanoparticles on cellulose paper sheets [164]. The paper was subsequently coated with polydopamine film, which acts as a link and then used as an immunoassay platform for detection. The material can be applied in medical applications due to low cost and easy manufacturing. Terbium-doped germanium borosilicate glass as a magnetic source was loaded into cellulose, and the incorporation with graphene oxide managed to fabricate a magnetic cellulose paper [165]. Homogeneous stirring and electrostatic interaction will disperse the magnetic and graphene oxide particles, therefore improving the mechanical and magnetic properties of cellulose-based papers.

\subsubsection{Electrical Responsive}

CNF films exhibited piezoelectric properties that could withstand high electric fields despite its porous structure [166]. The piezoelectric properties showed a significant increase after the introduction of electric field due to the high crystalline region with a large piezoelectric coefficient. The produced films exhibited permittivity of 3.47 and 3.38 when tested with dielectric potentials of $1 \mathrm{kHz}$ and $9.97 \mathrm{GHz}$, respectively; hence, the films are suitable in applications such as piezoelectric sensors, energy 
generators, and actuators. A CNF/polydimethylsiloxane composite used to fabricate piezoelectric nanogenerators exhibited high output piezoelectric signals with the voltage of $60.2 \mathrm{~V}$, which were able to power 19 blue LEDs and a charge capacitor up to $3.7 \mathrm{~V} \mathrm{[167].} \mathrm{This} \mathrm{composite} \mathrm{can} \mathrm{be} \mathrm{used} \mathrm{in}$ electronics and self-powered systems due to its high piezoelectric properties. Lower piezoelectric properties were observed when cellulose microfiber was used instead of nanocellulose due to the high amorphous region in native cellulose [168].

\subsubsection{PH Responsive}

Functionalized CNC and polyethylene glycol-poly(e-caprolactone)-based polyurethane composite were used to fabricate a $\mathrm{pH}$-responsive shape-memory polymer. The functionalization of CNC using pyridine and carboxyl groups induced the $\mathrm{pH}$ responsiveness of $\mathrm{CNC}$ through the hydrogen bond interaction at different $\mathrm{pH}$. The fabricated $\mathrm{pH}$-responsive polymer can be used as sensors, actuators, and biocompatible materials in biomedical engineering. Oxidized $\mathrm{CNC}$ can also be used in the fabrication of $\mathrm{pH}$ responsive sensors since the material shows reversible color changes at different $\mathrm{pH}$ values [169]. These characteristics assist in the development of bio-based sensors for chemical detection and intelligent packing materials.

\subsection{D Printing of Cellulose-Based Responsive Materials}

The merging of 3D printing technology and cellulose-based smart materials will be able to fabricate 4D-printed cellulose-based materials that can change shape over external stimuli. Many types of cellulose that are responsive to various stimuli reviewed in the previous section are suitable for the production of $4 \mathrm{D}$ cellulose materials. As cellulose possesses many useful properties such as biocompatibility, biodegradability, high mechanical properties, and thermal stability, the material will be a driving factor for the fabrication of cellulose-based $4 \mathrm{D}$ materials for applications in tissue engineering and medical applications.

CNF-based printing that mimicked the plant cell structure was embedded in the acrylamide matrix [170]. Clay was added to improve the rheological properties of the ink to be printable and to maintain the shape fidelity of the structure. The printed structure was cured under UV light for the cross-linking of acrylamide monomer. Glucose was incorporated to minimize oxygen interruption in the UV curing process. As a result, cellulose fibrils were well aligned, hence making the printed structure to have controlled swelling and exhibited anisotropy that induced reversible shape change with water stimulus. Through the variation of printing parameters, this hydrogel can be used to create structures that can change into the desired shapes after immersion in water.

Other than that, CMC, hydroxyethyl cellulose (HEC), and cellulose fiber composite were synthesized to study the characteristics and suitability of $4 \mathrm{D}$ printing of water stimulus cellulose-based structure [171]. Petal design was used to evaluate the shape-responsive properties to water stimulus. The hydration of the sample resulted in a flat surface and the dehydration resulted in a petal shape; furthermore, the configuration was cyclical as the cycle could be repeated more than five times, hence demonstrating good shape-memory behavior. A similar approach of HEC, microfibrillated cellulose (MFC), and lignin cross-linked with citric acid also demonstrated the shape-memory properties as the material became soft, expanded, and heavier after coming in contact with water stimulus [172]. Finite element method used in this study could be further explored for the fabrication of prototypes and desired structures for evaluating the shape-responsive properties. As this composite has higher mechanical properties and shape-responsive feature, the composite can be utilized in various biomedical applications.

Other than water stimulus, cellulose, and PVA composite cross-linked with glyoxal were 3D printed and it was found that the printed structure had shape-memory properties responsive to heat and moisture [173]. The $\mathrm{T}_{\mathrm{g}}$ of the composite was $70{ }^{\circ} \mathrm{C}$ and its state could be changed by heating above the temperature. The shape memory of the printed tensile bars was tested by heating above $\mathrm{T}_{\mathrm{g}}$ for temporary shape programming and cooling below $\mathrm{T}_{\mathrm{g}}$ with the stress maintained. The desired 
printed shape was obtained after heating above $\mathrm{T}_{\mathrm{g}}$ or immersing in water at $37{ }^{\circ} \mathrm{C}$ within $90 \mathrm{~min}$. The developed method has potential applications in the biomedical industry because the method can be moisture- and heat-triggered to have shape-memory properties, as well as to improve biodegradability as cellulose-based waste materials can also be incorporated.

Furthermore, stimulus responsive properties of N-isopropylarcylamide, CMC, arcylamide, and sodium alginate composite were studied using heat stimulus [174]. Various structures printed from the composite solution such as angulated and rounded patterns, T-shaped, and spring-shaped structures. The structures could undergo a transformation in different ways such as spring structure could be formed from C-shaped structure, as shown in Figure 9. 4D printing of cellulose-based materials will be essential in biomedical engineering applications, especially for tissue-based applications and soft robotic applications. Table 6 reviews the studies done on $4 \mathrm{D}$-printed cellulose-based materials using LDM technique.

(a)

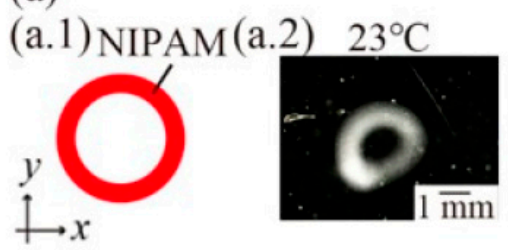

(b)
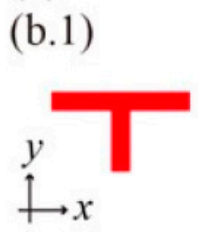

(c) (b. 2

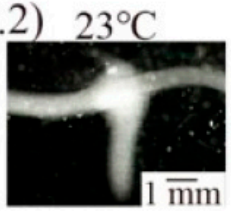

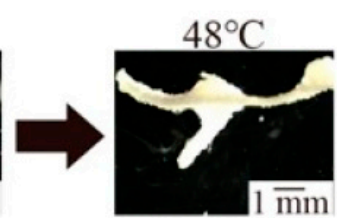

$1 \overline{\mathrm{m} m}$

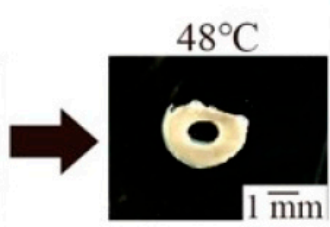

$1 \overline{\mathrm{mm}}$

(d)

(d.1)
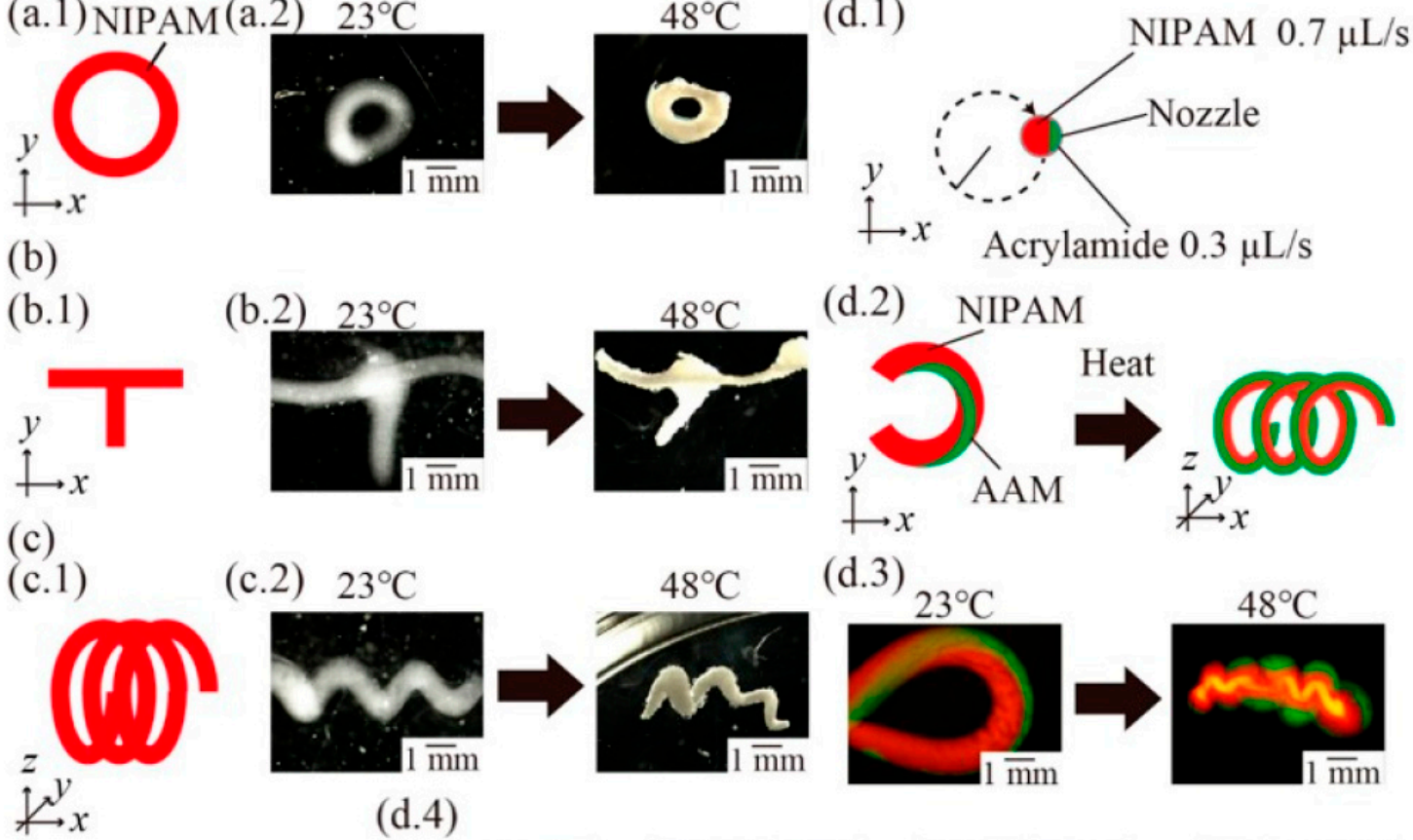

(c. 2) $23^{\circ} \mathrm{C}$
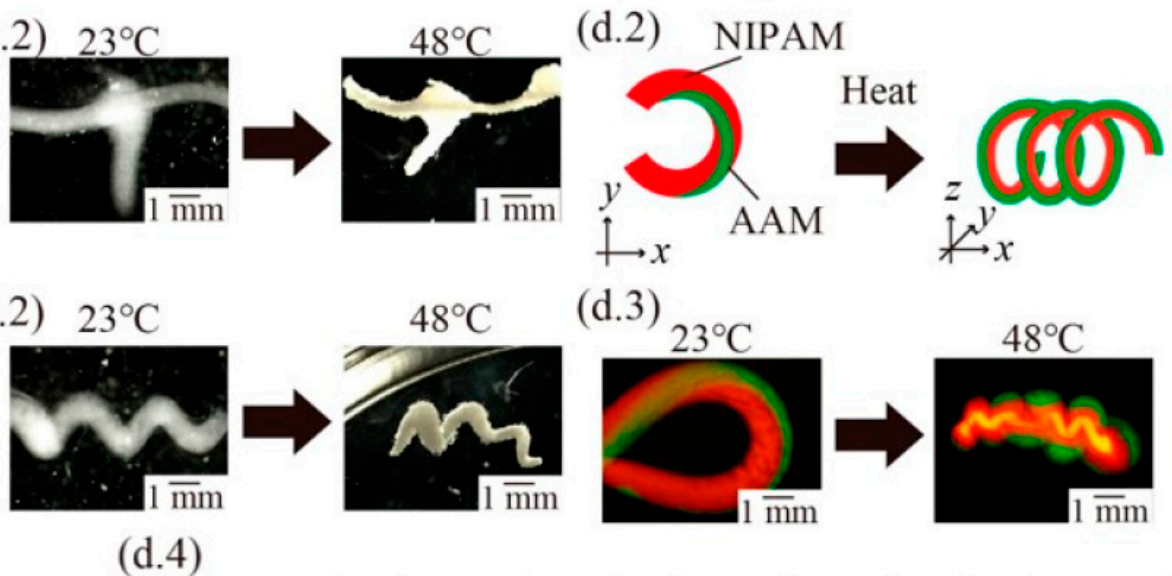

(d.3)
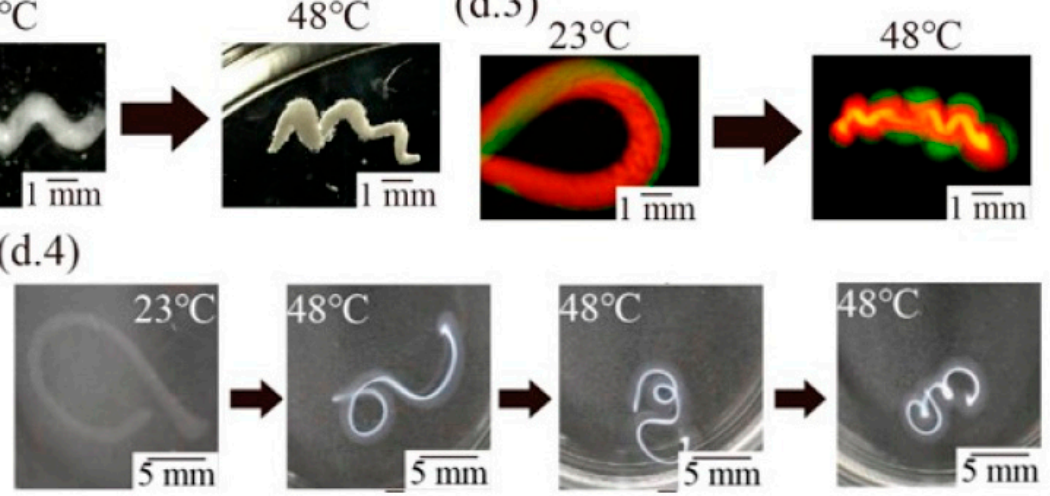

Figure 9. A demonstration of 4D printing: (a) schematic illustration and images of printed structures and heated structures with a rounded pattern; (b) schematic illustration and images of a fabricated T-shaped structure and a heated T-shaped structure with a cross point; (c) schematic illustration and images of a fabricated spring structure and heated spring structure with an internal gap; and (d) schematic illustrations of printing a C-shaped structure with multi-hydrogels (d.1) and its 3D deformation from the C-shaped structure to the spring-shaped structure. (d.2) Fluorescence images of the fabricated C-shaped structure (d.3) and the transformed spring structure obtained by heating. (d.4) Time-lapse images of the C-shaped structure [174]. 
Table 6. Review of 4D printed cellulose based materials using LDM technique.

\begin{tabular}{|c|c|c|c|c|c|c|}
\hline Cellulose Composition & 3D Printer & Printing Parameter & $\begin{array}{l}\text { Solidification } \\
\text { Method }\end{array}$ & Stimulus & $\begin{array}{c}\text { Potential } \\
\text { Application }\end{array}$ & Ref. \\
\hline $\begin{array}{c}\text { CNF, clay, } \\
\text { N-isopropylacrylamide }\end{array}$ & $\begin{array}{l}\text { ABG 10000, } \\
\text { Aerotech }\end{array}$ & Nozzle $0.15-1.5 \mathrm{~mm}$ & UV Curing & Water & $\begin{array}{l}\text { Tissue } \\
\text { engineering } \\
\text { and soft } \\
\text { robotics } \\
\text { applications }\end{array}$ & [170] \\
\hline $\begin{array}{l}\text { CMC, cellulose fibers, } \\
\text { HEC, clay }\end{array}$ & Prusa MK2 & $\begin{array}{l}\text { Nozzle } 0.8 \mathrm{~mm} \text {, layer } \\
\text { height } 0.6 \mathrm{~mm}\end{array}$ & $\begin{array}{l}\text { Crosslinked with } \\
\text { citric acid }\end{array}$ & Water & $\begin{array}{c}\text { Tissue } \\
\text { engineering } \\
\text { applications }\end{array}$ & [171] \\
\hline $\begin{array}{c}\text { HEC, MFC, citric } \\
\text { acid/hydrochloric acid, } \\
\text { lignin }\end{array}$ & $\begin{array}{l}\text { Modified } \\
\text { TEVO } \\
\text { Tarantula i3 }\end{array}$ & Nozzle $0.55-4 \mathrm{~mm}$ & $\begin{array}{l}\text { Crosslinking using } \\
\text { citric } \\
\text { acid/hydrochloric acid }\end{array}$ & Water & $\begin{array}{l}\text { Biomedical } \\
\text { application }\end{array}$ & [172] \\
\hline MFC, PVA & $\begin{array}{c}\text { 3D } \\
\text { Bioplotter, } \\
\text { EnvisionTEC }\end{array}$ & $\begin{array}{l}\text { Extrusion pressure } \\
5.0 \mathrm{bar} \text {, print speed xy } \\
400 \mathrm{~mm} / \mathrm{min} \text {, print } \\
\text { speed Z } 350 \mathrm{~mm} / \mathrm{min} \text {, } \\
\text { layer thickness } 0.67 \mathrm{~mm}\end{array}$ & $\begin{array}{l}\text { Crosslink using } \\
\text { glyoxal solution }\end{array}$ & $\begin{array}{l}\text { Heat and } \\
\text { Water }\end{array}$ & $\begin{array}{l}\text { Tissue } \\
\text { engineering } \\
\text { applications }\end{array}$ & [173] \\
\hline $\begin{array}{l}\mathrm{N} \text {-isopropylacrylamide, } \\
\mathrm{CMC} \text {, sodium alginate, } \\
\text { acrylamide }\end{array}$ & $\begin{array}{l}\text { Custom built } \\
\text { printer }\end{array}$ & $\begin{array}{c}\text { Extrusion flow rate } 1.0 \\
\mu \mathrm{L} / \mathrm{s}, \text { print speed } 1.0 \\
\mathrm{~mm} / \mathrm{s}\end{array}$ & $\begin{array}{l}\text { Irradiation with UV } \\
\text { light, then soaked in } \\
\text { water }\end{array}$ & Heat & $\begin{array}{l}\text { Environmental } \\
\text { monitoring } \\
\text { and medical } \\
\text { applications }\end{array}$ & [174] \\
\hline CMC-Na, clay, HEC & N/A & N/A & $\begin{array}{l}\text { Crosslinking with } \\
\text { citric acid }\end{array}$ & Water & $\begin{array}{c}\text { Tissue } \\
\text { engineering } \\
\text { applications }\end{array}$ & [175] \\
\hline $\begin{array}{c}\text { CMC-Na, } \\
\text { montmorillonite clay }\end{array}$ & N/A & N/A & $\begin{array}{l}\text { Crosslinking with } \\
\text { citric acid }\end{array}$ & Water & $\begin{array}{l}\text { Tissue } \\
\text { engineering } \\
\text { applications }\end{array}$ & [176] \\
\hline
\end{tabular}

\section{Summary, Conclusions, and Future Trends}

$\mathrm{AM}$ is a growing industry, and continuous research is being done to improve the technology and materials available. The development of materials with composites enables the fabrication of products with better mechanical properties, which can be fine-tuned according to the demand. AM enables the fabrication of customized products according to customer's design requirement and offers design flexibilities. AM plays a vital role in reducing the burden of traditional manufacturing processes in the fabrication of prototypes and testing the properties of the printed products.

Currently, more sustainable materials are preferred; as most of the AM materials are made from non-renewable resources, naturally-derived materials are adapted, and new studies are being done to improve interfacial adhesion and voidance for the application in various fields. Some applications such as wound healing or drug delivery cannot adapt AM until natural polymers are adopted as they are biocompatible. The proof of concept and in vivo studies are being continuously done in order to use natural-based materials for AM so that the applications can be broadened, where the materials will be the future trend of material development.

Cellulose, which is mainly derived from lignocellulosic biomass, possesses various useful properties; hence, more studies should be done to incorporate cellulose in AM. The potential of cellulose materials in AM is yet to be fully tapped, even though major developments can be seen in recent years with studies being conducted for various applications. Surface grafting of cellulose can nullify the hydrophilicity of cellulose, and hence voidance and interfacial adhesion can be improved. Further research should be carried out continuously to improve the mechanical properties so that AM-fabricated products will have better mechanical properties than traditionally-manufactured products. The increment of cellulose percentage in 3D printing filaments is also essential to improve the biodegradability of filaments and reduce the burden on petroleum resources, as well as to protect the environment as petroleum-based materials emit unpleasant odors.

Liquid deposition modeling of cellulose materials should also be further studied as the rheological properties of cellulose and cellulose derivatives favor the extrusion process. A high concentration of cellulose should be incorporated due to its high mechanical properties, and the structure of the printed 
part can be maintained after printing. Studies have shown that in vivo 3D-printed BC was able to cure diabetic wounds within four months, and many more studies should be done to present further proof. Cellulose materials can be synthesized with the desired properties according to the needs of applications and incorporated in AM for various types of applications with the developing technology.

$4 \mathrm{D}$ printing of bio-based materials is a newer technology compared to other AM-based technologies. Cellulose-based $4 \mathrm{D}$ printing materials are majorly developed based on water and heat stimuli. Further studies should be done on other stimulus-responsive cellulose-based materials for $4 \mathrm{D}$ printing, as vast cellulose smart materials are available and developed continuously. The development of cellulose-based $4 \mathrm{D}$ printing will contribute majorly in tissue engineering and drug delivery application, which can also change the prospect of the healthcare industry in the treatment of patients by using AM technologies.

Author Contributions: Conceptualization, D.M. and M.S.S.; writing—original draft preparation, D.M., Z.K.T. and A.N.B.; writing-review and editing, D.M., M.S.S. and H.K.; and funding acquisition, M.S.S. All authors have read and agreed to the published version of the manuscript.

Funding: This research was funded by Universiti Kebangsaan Malaysia through the grant provided, DIP-2020-006 and MRUN-RAKAN RU-2019-004/4.

Conflicts of Interest: The authors declare no conflict of interest.

\section{References}

1. Wadley, D. The City of Grace: An Urban Manifesto; Springer Nature Singapore Pte Ltd.: Gateway East, Singapore, 2020; pp. 1-12.

2. Corolleur, F.; Matt, M.; Perez, S. Innovation potentials triggered by glycoscience research. Carbohydr. Polym. 2020, 233, 115833. [CrossRef] [PubMed]

3. Nguyen, H.T.H.; Qi, P.; Rostagno, M.; Feteha, A.; Miller, S.A. The quest for high glass transition temperature bioplastics. J. Mater. Chem. A 2018, 6, 9298-9331. [CrossRef]

4. Neufeld, L.; Stassen, F.; Sheppard, R.; Gilman, T. The New Plastics Economy: Rethinking the Future of Plastics; World Economic Forum: Cologne, Switzerland, 2016; Volume 7, pp. 1-36.

5. Iacovidou, E.; Velenturf, A.P.M.; Purnell, P. Quality of resources: A typology for supporting transitions towards resource efficiency using the single-use plastic bottle as an example. Sci. Total Environ. 2019, 647, 441-448. [CrossRef] [PubMed]

6. Nakajima, H.; Dijkstra, P.; Loos, K. The recent developments in biobased polymers toward general and engineering applications: Polymers that are upgraded from biodegradable polymers, analogous to petroleum-derived polymers, and newly developed. Polymers 2017, 9, 523. [CrossRef]

7. O'Dea, R.M.; Willie, J.A.; Epps III, T.H. 100th Anniversary of Macromolecular Science Viewpoint: Polymers from Lignocellulosic Biomass. Current Challenges and Future Opportunities. ACS Macro. Lett. 2020, 9, 476-493. [CrossRef]

8. Lucia, L.A. Lignocellulosic biomass: A potential feedstock to replace petroleum. BioResources 2008, 3, 981-982.

9. Pasangulapati, V.; Ramachandriya, K.D.; Kumar, A.; Wilkins, M.R.; Jones, C.L.; Huhnke, R.L. Effects of cellulose, hemicellulose and lignin on thermochemical conversion characteristics of the selected biomass. Bioresour. Technol. 2012, 114, 663-669. [CrossRef]

10. Ibrahim, F.; Mohan, D.; Sajab, M.S.; Bakarudin, S.B.; Kaco, H. Evaluation of the Compatibility of Organosolv Lignin-Graphene Nanoplatelets with Photo-Curable Polyurethane in Stereolithography 3D Printing. Polymers 2019, 11, 1544. [CrossRef]

11. Sun, S.; Sun, S.; Cao, X.; Sun, R. The role of pretreatment in improving the enzymatic hydrolysis of lignocellulosic materials. Bioresour. Technol. 2016, 199, 49-58. [CrossRef]

12. Lu, Y.; Lu, Y.C.; Hu, H.Q.; Xie, F.J.; Wei, X.Y.; Fan, X. Structural characterization of lignin and its degradation products with spectroscopic methods. J. Spectrosc. 2017, 2017, 1-15. [CrossRef]

13. Awalludin, M.F.; Sulaiman, O.; Hashim, R.; Nadhari, W.N.A.W. An overview of the oil palm industry in Malaysia and its waste utilization through thermochemical conversion, specifically via liquefaction. Renew. Sustain. Energy Rev. 2015, 50, 1469-1484. [CrossRef] 
14. Charreau, H.; Cavallo, E.; Foresti, M.L. Patents involving nanocellulose: Analysis of their evolution since 2010. Carbohydr. Polym. 2020, 237, 116039. [CrossRef] [PubMed]

15. Mishra, S.; Kharkar, P.S.; Pethe, A.M. Biomass and waste materials as potential sources of nanocrystalline cellulose: Comparative review of preparation methods (2016 - Till date). Carbohydr. Polym. 2019, 207, 418-427. [CrossRef] [PubMed]

16. Salimi, S.; Sotudeh-gharebagh, R.; Zarghami, R.; Chan, S.Y.; Yuen, K.H. Production of Nanocellulose and Its Applications in Drug Delivery: A Critical Review. ACS Sustain. Chem. Eng. 2019, 7, 15800-15827. [CrossRef]

17. Mohan, D.; Sajab, M.S.; Kaco, H.; Bakarudin, S.B.; Mohamed Noor, A. 3D Printing of UV-Curable Polyurethane Incorporated with Surface-Grafted Nanocellulose. Nanomaterials 2019, 9, 1726. [CrossRef]

18. Parandoush, P.; Lin, D. A review on additive manufacturing of polymer-fiber composites. Compos. Struct. 2017, 182, 36-53. [CrossRef]

19. Mazzanti, V.; Malagutti, L.; Mollica, F. FDM 3D printing of polymers containing natural fillers: A review of their mechanical properties. Polymers 2019, 11, 1094. [CrossRef]

20. Jain, A.; Mathur, T.; Pandian, N.K.R.; Selahi, A. Organ-on-a-chip and 3D printing as preclinical models for medical research and practice. In Precision Medicine for Investigators, Practitioners and Providers; Elsevier Ltd.: Duxford, UK, 2020; Chapter 9; pp. 83-95.

21. Durfee, K.; Iaizzo, P.A. Medical Applications of 3D Printing. In Engineering in Medicine; Elsevier Ltd.: Duxford, UK, 2019; Chapter 21; pp. 495-509.

22. Visser, C.W.; Pohl, R.; Sun, C.; Romer, G.W.; Huis in't Veld, B.; Lohse, D. Toward 3D Printing of Pure Metals by Laser-Induced Forward Transfer. Adv. Mater. 2015, 27, 4087-4092. [CrossRef]

23. Chen, Z.; Li, Z.; Li, J.; Liu, C.; Lao, C.; Fu, Y.; Liu, C.; Li, Y.; Wang, P.; He, Y. 3D printing of ceramics: A review. J. Eur. Ceram. Soc. 2019, 39, 661-687. [CrossRef]

24. Zhang, D.; Jonhson, W.; Herng, T.S.; Ang, Y.Q.; Yang, L.; Tan, S.C.; Peng, E.; He, H.; Ding, J. A 3D-printing method of fabrication for metals, ceramics, and multi-materials using a universal self-curable technique for robocasting. Mater. Horizons 2020, 7, 1083-1090. [CrossRef]

25. Potter, P.M.; Al-Abed, S.R.; Lay, D.; Lomnicki, S.M. VOC Emissions and Formation Mechanisms from Carbon Nanotube Composites During 3D Printing. Environ. Sci. Technol. 2019, 53, 4364-4370. [CrossRef]

26. Ligon, S.C.; Liska, R.; Stampfl, J.; Gurr, M.; Mülhaupt, R. Polymers for 3D Printing and Customized Additive Manufacturing. Chem. Rev. 2017, 117, 10212-10290. [CrossRef] [PubMed]

27. Ma, C.; Jiang, L.; Wang, Y.; Gang, F.; Xu, N.; Li, T.; Liu, Z.; Chi, Y.; Wang, X.; Zhao, L.; et al. 3D Printing of Conductive Tissue Engineering Scaffolds Containing Polypyrrole Nanoparticles with Different Morphologies and Concentrations. Materials 2019, 12, 2491. [CrossRef]

28. Wang, C.; Huang, W.; Zhou, Y.; He, L.; He, Z.; Chen, Z.; He, X.; Tian, S.; Liao, J.; Lu, B.; et al. 3D printing of bone tissue engineering scaffolds. Bioact. Mater. 2020, 5, 82-91. [CrossRef] [PubMed]

29. Tao, O.; Kort-Mascort, J.; Lin, Y.; Pham, H.M.; Charbonneau, A.M.; ElKashty, O.A.; Kinsella, J.M.; Tran, S.D. The Applications of 3D Printing for Craniofacial Tissue Engineering. Micromachines 2019, 10, 480. [CrossRef]

30. Inzana, J.A.; Olvera, D.; Fuller, S.M.; Kelly, J.P.; Graeve, O.A.; Schwarz, E.M.; Kates, S.L.; Awad, H.A. 3D printing of composite calcium phosphate and collagen scaffolds for bone regeneration. Biomaterials 2014, 35, 4026-4034. [CrossRef] [PubMed]

31. Wu, Q.; Maire, M.; Lerouge, S.; Therriault, D.; Heuzey, M.-C. 3D Printing of Microstructured and Stretchable Chitosan Hydrogel for Guided Cell Growth. Adv. Biosyst. 2017, 1, 1700058. [CrossRef]

32. Yang, X.; Lu, Z.; Wu, H.; Li, W.; Zheng, L.; Zhao, J. Collagen-alginate as bioink for three-dimensional (3D) cell printing based cartilage tissue engineering. Mater. Sci. Eng. C 2017, 83, 195-201. [CrossRef]

33. Shahrubudin, N.; Lee, T.; Ramlan, R. An Overview on 3D Printing Technology: Technological, Materials, and Applications. Procedia Manuf. 2019, 35, 1286-1296. [CrossRef]

34. Redwood, B. Additive Manufacturing Technologies: An Overview. Available online: https://www.3dhubs. com/knowledge-base/additive-manufacturing-technologies-overview/ (accessed on 10 August 2020).

35. Harikrishnan, U.; Soundarapandian, S. Fused Deposition Modelling based Printing of Full Complement Bearings. Procedia Manuf. 2018, 26, 818-825. [CrossRef]

36. Gibson, I.; Rosen, D.W.; Stucker, B. Vat Photopolymerization Processes. In Additive Manufacturing Technologies; Springer: New York, NY, USA, 2010; Chapter 11; pp. 299-332.

37. Kunchala, P.; Kappagantula, K. 3D printing high density ceramics using binder jetting with nanoparticle densifiers. Mater. Des. 2018, 155, 443-450. [CrossRef] 
38. Hossain, M.S.; Gonzalez, J.A.; Hernandez, R.M.; Shuvo, M.A.I.; Mireles, J.; Choudhuri, A.; Lin, Y.; Wicker, R.B. Fabrication of smart parts using powder bed fusion additive manufacturing technology. Addit. Manuf. 2016, 10, 58-66. [CrossRef]

39. Yap, Y.L.; Wang, C.; Sing, S.L.; Dikshit, V.; Yeong, W.Y.; Wei, J. Material jetting additive manufacturing: An experimental study using designed metrological benchmarks. Precis. Eng. 2017, 50, 275-285. [CrossRef]

40. Rahman, N.U.; Capuano, L.; Cabeza, S.; Feinaeugle, M.; Garcia-Junceda, A.; De Rooij, M.; Matthews, D.; Walmag, G.; Gibson, I.; Römer, G. Directed energy deposition and characterization of high-carbon high speed steels. Addit. Manuf. 2019, 30, 100838. [CrossRef]

41. Diegel, O.; Nordin, A.; Motte, D. A Practical Guide to Design for Additive Manufacturing; Springer Nature Singapore Pte Ltd.: Gateway East, Singapore, 2020; Chapter 2; pp. 19-39.

42. Dizon, J.R.C.; Espera, A.H.; Chen, Q.; Advincula, R.C. Mechanical characterization of 3D-printed polymers. Addit. Manuf. 2018, 20, 44-67. [CrossRef]

43. Wohlers, T.T. 3D Printing and Additive Manufacturing State of the Industry; Wohlers Report; WOHLERS Associates: Fort Collins, CO, USA, 2017.

44. Dong, M.; Zhang, S.; Gao, D.; Chou, B. The study on polypropylene applied in fused deposition modeling. In Proceedings of the AIP Conference Proceedings, Taipei, Taiwan, 24 May 2018.

45. Drzyzga, O.; Prieto, A. Plastic waste management, a matter for the 'community'. Microb. Biotechnol. 2019, 12, 66-68. [CrossRef]

46. Smith, A.M.; Moxon, S.; Morris, G.A. Biopolymers as wound healing materials. In Wound Healing Biomaterials; Woodhead Publishing Ltd.: Cambridge, UK, 2016; Volume 2, Chapter 13; pp. 261-287.

47. Laycock, B.; Nikolić, M.; Colwell, J.M.; Gauthier, E.; Halley, P.; Bottle, S.; George, G. Lifetime prediction of biodegradable polymers. Prog. Polym. Sci. 2017, 71, 144-189. [CrossRef]

48. Glaser, J.A. Biological degradation of polymers in the environment. In Plastics in the Environment; Gomiero, A., Ed.; Intechopen: London, UK, 2019; Chapter 5; p. 675.

49. Emadian, S.M.; Onay, T.T.; Demirel, B. Biodegradation of bioplastics in natural environments. Waste Manag. 2017, 59, 526-536. [CrossRef]

50. Zhao, C.Q.; Liu, W.G.; Xu, Z.Y.; Li, J.G.; Huang, T.T.; Lu, Y.J.; Huang, H.G.; Lin, J.X. Chitosan ducts fabricated by extrusion-based 3D printing for soft-tissue engineering. Carbohydr. Polym. 2020, 236, 116058. [CrossRef]

51. Wei, L.; Wu, S.; Kuss, M.; Jiang, X.; Sun, R.; Reid, P.; Qin, X.; Duan, B. 3D printing of silk fibroin-based hybrid scaffold treated with platelet rich plasma for bone tissue engineering. Bioact. Mater. 2019, 4, 256-260. [CrossRef]

52. Li, N.; Li, Y.; Liu, S. Rapid prototyping of continuous carbon fiber reinforced polylactic acid composites by 3D printing. J. Mater. Process. Technol. 2016, 238, 218-225. [CrossRef]

53. Heidari-Rarani, M.; Rafiee-Afarani, M.; Zahedi, A.M. Mechanical characterization of FDM 3D printing of continuous carbon fiber reinforced PLA composites. Compos. Part B Eng. 2019, 175, 107147. [CrossRef]

54. Prashantha, K.; Roger, F. Multifunctional properties of 3D printed poly(lactic acid)/graphene nanocomposites by fused deposition modeling. J. Macromol. Sci. A 2017, 54, 24-29. [CrossRef]

55. Wu, C.S.; Tsou, C.H. Fabrication, characterization, and application of biocomposites from poly(lactic acid) with renewable rice husk as reinforcement. J. Polym. Res. 2019, 26, 44. [CrossRef]

56. Liu, Z.; Lei, Q.; Xing, S. Mechanical characteristics of wood, ceramic, metal and carbon fiber-based PLA composites fabricated by FDM. J. Mater. Res. Technol. 2019, 8, 3741-3751. [CrossRef]

57. Zhao, X.; Tekinalp, H.; Meng, X.; Ker, D.; Benson, B.; Pu, Y.; Ragauskas, A.J.; Wang, Y.; Li, K.; Webb, E.; et al. Poplar as Biofiber Reinforcement in Composites for Large-Scale 3D Printing. ACS Appl. Bio Mater. 2019, 2, 4557-4570. [CrossRef]

58. Varga, P.; Lorinczy, D.; Toth, L.; Pentek, A.; Nyitrai, M.; Maroti, P. Novel PLA-CaCO 3 composites in additive manufacturing of upper limb casts and orthotics-a feasibility study. Mater. Res. Express 2019, 6. [CrossRef]

59. Tanase-Opedal, M.; Espinosa, E.; Rodríguez, A.; Chinga-Carrasco, G. Lignin: A biopolymer from forestry biomass for biocomposites and 3D printing. Materials 2019, 12, 3006. [CrossRef]

60. Dong, Y.; Milentis, J.; Pramanik, A. Additive manufacturing of mechanical testing samples based on virgin poly (lactic acid) (PLA) and PLA/wood fibre composites. Adv. Manuf. 2018, 6, 71-82. [CrossRef]

61. Daver, F.; Lee, K.P.M.; Brandt, M.; Shanks, R. Cork-PLA composite filaments for fused deposition modelling. Compos. Sci. Technol. 2018, 168, 230-237. [CrossRef] 
62. Kavitha, A.A.; Paul, K.T.; Anilkumar, P. Cellulose-derived materials for drug delivery applications. In Sustainable Nanocellulose and Nanohydrogels from Natural Sources; Elsevier Ltd.: Duxford, UK, 2020; Chapter 18; pp. 367-390.

63. Tosh, B. Synthesis and Sustainable Applications of Cellulose Esters and Ethers : A Review. Int. J. Energy, Sustain. Environ. Eng. 2014, 1, 2.

64. Ioelovich, M.; Leykin, A.; Haemek, M. Formation Nano-Structure of Microcrystalline Cellulose. Cell. Chem. Technol. 2006, 40, 313-317.

65. Hua, Y.L.; Harun, S.; Sajab, M.S.; Jahim, J.M.; Shah, S.S.M. Extraction of Cellulose and Microcrystalline Cellulose from Kenaf. Jurnal Kejuruteraan 2020, 32, 205-213.

66. Xian, X.; Wang, X.; Zhu, Y.; Guo, Y.; Tian, Y. Effects of MCC Content on the Structure and Performance of PLA/MCC Biocomposites. J. Polym. Environ. 2018, 26, 3484-3492. [CrossRef]

67. Long, W.J.; Tao, J.L.; Lin, C.; Gu, Y.C.; Mei, L.; Duan, H.B.; Xing, F. Rheology and buildability of sustainable cement-based composites containing micro-crystalline cellulose for 3D-printing. J. Clean. Prod. 2019, 239, 118054. [CrossRef]

68. Nsor-Atindana, J.; Chen, M.; Goff, H.D.; Zhong, F.; Sharif, H.R.; Li, Y. Functionality and nutritional aspects of microcrystalline cellulose in food. Carbohydr. Polym. 2017, 172, 159-174. [CrossRef]

69. Saputra, A.H.; Qadhayna, L.; Pitaloka, A.B. Synthesis and Characterization of Carboxymethyl Cellulose (CMC) from Water Hyacinth Using Ethanol-Isobutyl Alcohol Mixture as the Solvents. Int. J. Chem. Eng. Appl. 2014, 5, 36. [CrossRef]

70. Abdulkhani, A.; Najd, A.; Sahab, M.; Yahya, H. Preparation of xylan bio - composite films reinforced with oxidized carboxymethyl cellulose and nanocellulose. Polym. Bull. 2019, 1-13. [CrossRef]

71. Dürig, T.; Karan, K. Binders in Wet Granulation. In Handbook of Pharmaceutical Wet Granulation; Academic Press: Cambridge, MA, USA, 2019; Chapter 9; pp. 317-349.

72. Aravamudhan, A.; Ramos, D.M.; Nada, A.A.; Kumbar, S.G. Natural and Synthetic Biomedical Polymers; Elsevier Inc.: Amsterdam, The Netherlands, 2014; Chapter 4; pp. 67-89.

73. Chen, L.; Wang, Q.; Hirth, K.; Baez, C.; Agarwal, U.P.; Zhu, J.Y. Tailoring the yield and characteristics of wood cellulose nanocrystals (CNC) using concentrated acid hydrolysis. Cellulose 2015, 22, 1753-1762. [CrossRef]

74. Xie, H.; Du, H.; Yang, X.; Si, C. Recent Strategies in Preparation of Cellulose Nanocrystals and Cellulose Nanofibrils Derived from Raw Cellulose Materials. Int. J. Polym. Sci. 2018, 2018, 1-25. [CrossRef]

75. Shankaran, D.R. Cellulose Nanocrystals for Healthcare Applications. In Application of Nanomaterials; Elsevier Ltd.: Duxford, UK, 2018; Chapter 14; pp. 415-459.

76. Khanjanzadeh, H.; Behrooz, R.; Bahramifar, N.; Pinkl, S.; Gindl-Altmutter, W. Application of surface chemical functionalized cellulose nanocrystals to improve the performance of UF adhesives used in wood based composites-MDF type. Carbohydr. Polym. 2019, 206, 11-20. [CrossRef] [PubMed]

77. Sajab, M.S.; Mohan, D.; Santanaraj, J.; Chia, C.H.; Kaco, H.; Harun, S.; Kamarudin, N.H.N. Telescopic synthesis of cellulose nanofibrils with a stable dispersion of $\mathrm{Fe}(0)$ nanoparticles for synergistic removal of 5-fluorouracil. Sci. Rep. 2019, 9, 11703. [CrossRef] [PubMed]

78. Chan, C.H.; Chia, C.H.; Zakaria, S.; Sajab, M.S.; Chin, S.X. Cellulose nanofibrils: A rapid adsorbent for the removal of methylene blue. RSC Adv. 2015, 5, 18204-18212. [CrossRef]

79. Mariani, L.M.; Johnson, W.R.; Considine, J.M.; Turner, K.T. Printing and mechanical characterization of cellulose nanofibril materials. Cellulose 2019, 26, 2639-2651. [CrossRef]

80. Wang, X.; Chang, C.H.; Jiang, J.; Liu, Q.; Liao, Y.P.; Lu, J.; Li, L.; Liu, X.; Kim, J.; Ahmed, A.; et al. The Crystallinity and Aspect Ratio of Cellulose Nanomaterials Determine Their Pro-Inflammatory and Immune Adjuvant Effects in Vitro and In Vivo. Small 2019, 15, 1901642. [CrossRef]

81. Abudula, T.; Saeed, U.; Memic, A.; Gauthaman, K.; Hussain, M.A.; Al-Turaif, H. Electrospun cellulose Nano fibril reinforced PLA/PBS composite scaffold for vascular tissue engineering. J. Polym. Res. 2019, 26, 110. [CrossRef]

82. Costa, A.F.S.; Almeida, F.C.G.; Vinhas, G.M.; Sarubbo, L.A. Production of bacterial cellulose by Gluconacetobacter hansenii using corn steep liquor as nutrient sources. Front. Microbiol. 2017, 8, 2027. [CrossRef]

83. Eslahi, N.; Mahmoodi, A.; Mahmoudi, N.; Zandi, N.; Simchi, A. Processing and Properties of Nanofibrous Bacterial Cellulose-Containing Polymer Composites: A Review of Recent Advances for Biomedical Applications. Polym. Rev. 2020, 60, 144-170. [CrossRef] 
84. Ramírez, J.A.Á.; Bovi, J.; Bernal, C.; Errea, M.I.; Foresti, M.L. Development of Poly(lactic acid) Nanocomposites Reinforced with Hydrophobized Bacterial Cellulose. J. Polym. Environ. 2020, 28, 61-73. [CrossRef]

85. Kaya, M.; Demir, A.; Akçay, H.T. A Novel Highly Porous Cellulosic Aerogel Regenerated by Solvent Exchange Mechanism. J. Polym. Environ. 2019, 27, 1801-1806. [CrossRef]

86. Felgueiras, H.P.; Teixeira, M.A.; Tavares, T.D.; Amorim, M.T.P. New method to produce poly(vinyl alcohol)/cellulose acetate films with improved antibacterial action. Mater. Today Proc. 2020. [CrossRef]

87. Murphy, C.A.; Collins, M.N. Microcrystalline cellulose reinforced polylactic acid biocomposite filaments for 3D printing. Polym. Compos. 2018, 39, 1311-1320. [CrossRef]

88. Wang, Q.; Ji, C.; Sun, J.; Yao, Q.; Liu, J.; Saeed, R.M.Y.; Zhu, Q. Kinetic thermal behavior of nanocellulose filled polylactic acid filament for fused filament fabrication 3D printing. J. Appl. Polym. Sci. 2019, 137, 48374. [CrossRef]

89. Dong, J.; Li, M.; Zhou, L.; Lee, S.; Mei, C.; Xu, X.; Wu, Q. The influence of grafted cellulose nanofibers and postextrusion annealing treatment on selected properties of poly(lactic acid) filaments for 3D printing. J. Polym. Sci. Part B Polym. Phys. 2017, 55, 847-855. [CrossRef]

90. Frone, A.N.; Batalu, D.; Chiulan, I.; Oprea, M.; Gabor, A.R.; Nicolae, C.-A.; Raditoiu, V.; Trusca, R.; Panaitescu, D.M. Morpho-Structural, Thermal and Mechanical Properties of PLA/PHB/Cellulose Biodegradable Nanocomposites Obtained by Compression Molding, Extrusion, and 3D Printing. Nanomaterials 2020, 10, 51. [CrossRef]

91. Li, L.; Chen, Y.; Yu, T.; Wang, N.; Wang, C.; Wang, H. Preparation of polylactic acid/TEMPO-oxidized bacterial cellulose nanocomposites for 3D printing via Pickering emulsion approach. Compos. Commun. 2019, 16, 162-167. [CrossRef]

92. Jiang, G.; Yang, T.; Xu, J.; Tao, D.; Luo, C.; Wang, C.; Dong, Q.; Wang, Y. Investigation into hydroxypropylmethylcellulose-reinforced polylactide composites for fused deposition modelling. Ind. Crops Prod. 2020, 146, 112174. [CrossRef]

93. Paggi, R.A.; Salmoria, G.V.; Ghizoni, G.B.; de Medeiros Back, H.; de Mello Gindri, I. Structure and mechanical properties of 3D-printed cellulose tablets by fused deposition modeling. Int. J. Adv. Manuf. Technol. 2019, 100, 2767-2774. [CrossRef]

94. Dong, J.; Mei, C.; Han, J.; Lee, S.; Wu, Q. 3D printed poly(lactic acid) composites with grafted cellulose nanofibers: Effect of nanofiber and post-fabrication annealing treatment on composite flexural properties. Addit. Manuf. 2019, 28, 621-628. [CrossRef]

95. Feng, X.; Yang, Z.; Rostom, S.S.H.; Dadmun, M.; Wang, S.; Wang, Q.; Xie, Y. Reinforcing 3D printed acrylonitrile butadiene styrene by impregnation of methacrylate resin and cellulose nanocrystal mixture: Structural effects and homogeneous properties. Mater. Des. 2018, 138, 62-70. [CrossRef]

96. Cisneros-López, E.O.; Pal, A.K.; Rodriguez, A.U.; Wu, F.; Misra, M.; Mielewski, D.F.; Kiziltas, A.; Mohanty, A.K. Recycled poly(lactic acid)-based 3D printed sustainable biocomposites: A comparative study with injection molding. Mater. Today Sustain. 2020, 8, 1-12. [CrossRef]

97. Coppola, B.; Garofalo, E.; Di Maio, L.; Scarfato, P.; Incarnato, L. Investigation on the use of PLA/hemp composites for the fused deposition modelling (FDM) 3D printing. In Proceedings of the AIP Conference Proceedings, Bali, Indonesia, 11 July 2018; Volume 1981, p. 020086.

98. Huang, B.; He, H.; Meng, S.; Jia, Y. Optimizing 3D printing performance of acrylonitrile-butadiene-styrene composites with cellulose nanocrystals/silica nanohybrids. Polym. Int. 2019, 68, 1351-1360. [CrossRef]

99. Alemán-Domínguez, M.E.; Giusto, E.; Ortega, Z.; Tamaddon, M.; Benítez, A.N.; Liu, C. Three-dimensional printed polycaprolactone-microcrystalline cellulose scaffolds. J. Biomed. Mater. Res. Part B Appl. Biomater. 2019, 107, 521-528. [CrossRef]

100. Zander, N.E.; Park, J.H.; Boelter, Z.R.; Gillan, M.A. Recycled Cellulose Polypropylene Composite Feedstocks for Material Extrusion Additive Manufacturing. ACS Omega 2019, 4, 13879-13888. [CrossRef] [PubMed]

101. Ahmad, M.N.; Wahid, M.K.; Maidin, N.A.; Ab Rahman, M.H.; Osman, M.H.; Alis, I.F. Mechanical characteristics of oil palm fiber reinforced thermoplastics as filament for fused deposition modeling (FDM). Adv. Manuf. 2020, 8, 72-81. [CrossRef]

102. Cataldi, A.; Rigotti, D.; Nguyen, V.D.H.; Pegoretti, A. Polyvinyl alcohol reinforced with crystalline nanocellulose for 3D printing application. Mater. Today Commun. 2018, 15, 236-244. [CrossRef] 
103. Feng, X.; Yang, Z.; Rostom, S.S.H.; Dadmun, M.; Xie, Y.; Wang, S. Structural, mechanical, and thermal properties of 3D printed L-CNC / acrylonitrile butadiene styrene nanocomposites. J. Appl. Polym. Sci. 2017, 134, 45082. [CrossRef]

104. Tekinalp, H.L.; Meng, X.; Lu, Y.; Kunc, V.; Love, L.J.; Peter, W.H.; Ozcan, S. High modulus biocomposites via additive manufacturing: Cellulose nanofibril networks as "microsponges". Compos. Part. B Eng. 2019, 173, 106817. [CrossRef]

105. Xiao, X.; Chevali, V.S.; Song, P.; He, D.; Wang, H. Polylactide/hemp hurd biocomposites as sustainable 3D printing feedstock. Compos. Sci. Technol. 2019, 184, 107887. [CrossRef]

106. Tran, T.N.; Bayer, I.S.; Heredia-Guerrero, J.A.; Frugone, M.; Lagomarsino, M.; Maggio, F.; Athanassiou, A. Cocoa shell waste biofilaments for 3D printing applications. Macromol. Mater. Eng. 2017, 302, 1700219. [CrossRef]

107. Palaganas, N.B.; Mangadlao, J.D.; de Leon, A.C.C.; Palaganas, J.O.; Pangilinan, K.D.; Lee, Y.J.; Advincula, R.C. 3D Printing of Photocurable Cellulose Nanocrystal Composite for Fabrication of Complex Architectures via Stereolithography. ACS Appl. Mater. Interf. 2017, 9, 34314-34324. [CrossRef] [PubMed]

108. Feng, X.; Yang, Z.; Chmely, S.; Wang, Q.; Wang, S.; Xie, Y. Lignin-coated cellulose nanocrystal filled methacrylate composites prepared via 3D stereolithography printing: Mechanical reinforcement and thermal stabilization. Carbohydr. Polym. 2017, 169, 272-281. [CrossRef]

109. Melilli, G.; Carmagnola, I.; Tonda-Turo, C.; Pirri, F.; Ciardelli, G.; Sangermano, M.; Hakkarainen, M.; Chiappone, A. DLP 3D Printing Meets Lignocellulosic Biopolymers: Carboxymethyl Cellulose Inks for 3D Biocompatible Hydrogels. Polymers 2020, 12, 1655. [CrossRef]

110. Chen, S.; Yang, J.; Jia, Y.-G.; Lu, B.; Ren, L. A Study of 3D-Printable Reinforced Composite Resin: PMMA Modified with Silver Nanoparticles Loaded Cellulose Nanocrystal. Materials 2018, 11, 2444. [CrossRef] [PubMed]

111. Yang, Z.; Wu, G.; Wang, S. Dynamic postpolymerization of 3D-printed photopolymer nanocomposites: Effect of cellulose nanocrystal and postcure temperature. J. Polym. Sci. Part B Polym. Phys. 2018, 56, 935-946. [CrossRef]

112. Lu, C.; Wang, C.; Yu, J.; Wang, J.; Chu, F. Two-Step 3 D-Printing Approach toward Sustainable, Repairable, Fluorescent Shape-Memory Thermosets Derived from Cellulose and Rosin. ChemSusChem 2020, 13, 893-902. [CrossRef] [PubMed]

113. Li, V.C.F.; Kuang, X.; Mulyadi, A.; Hamel, C.M.; Deng, Y.; Qi, H.J. 3D printed cellulose nanocrystal composites through digital light processing. Cellulose 2019, 26, 3973-3985. [CrossRef]

114. Gatenholm, P.; Martinez, H.; Karabulut, E.; Amoroso, M.; Kölby, L.; Markstedt, K.; Gatenholm, E.; Henriksson, I. Development of Nanocellulose-Based Bioinks for 3D Bioprinting of Soft Tissue. In 3D Printing and Biofabrication; Springer: Cham, Switzerland, 2018; pp. 331-352.

115. Markstedt, K.; Sundberg, J.; Gatenholm, P. 3D bioprinting of cellulose structures from an ionic liquid. 3D Print. Addit. Manuf. 2014, 1, 115-121. [CrossRef]

116. Pattinson, S.W.; Hart, A.J. Additive Manufacturing of Cellulosic Materials with Robust Mechanics and Antimicrobial Functionality. Adv. Mater. Technol. 2017, 2, 1600084. [CrossRef]

117. Li, V.C.F.; Dunn, C.K.; Zhang, Z.; Deng, Y.; Qi, H.J. Direct Ink Write (DIW) 3D Printed Cellulose Nanocrystal Aerogel Structures. Sci. Rep. 2017, 7, 8018. [CrossRef]

118. Brandley, A.; Hollfelder, R.; Nesaei, S.; Vanwie, B.; Abu-Lail, N.; Gozen, B.A. Direct-Ink-Writing of Degradable Carboxymethylcellulose. Procedia Manuf. 2018, 26, 993-1002. [CrossRef]

119. Habib, A.; Sathish, V.; Mallik, S.; Khoda, B. 3D Printability of Alginate-Carboxymethyl Cellulose Hydrogel. Materials 2018, 11, 454. [CrossRef] [PubMed]

120. Kam, D.; Chasnitsky, M.; Nowogrodski, C.; Braslavsky, I.; Abitbol, T.; Magdassi, S.; Shoseyov, O. Direct Cryo Writing of Aerogels Via 3D Printing of Aligned Cellulose Nanocrystals Inspired by the Plant Cell Wall. Colloids Interfaces 2019, 3, 46. [CrossRef]

121. Zuo, M.; Pan, N.; Liu, Q.; Ren, X.; Liu, Y.; Huang, T.S. Three-dimensionally printed polylactic acid/cellulose acetate scaffolds with antimicrobial effect. RSC Adv. 2020, 10, 2952-2958. [CrossRef]

122. Gutierrez, E.; Burdiles, P.A.; Quero, F.; Palma, P.; Olate-Moya, F.; Palza, H. 3D Printing of Antimicrobial Alginate/Bacterial-Cellulose Composite Hydrogels by Incorporating Copper Nanostructures. ACS Biomater. Sci. Eng. 2019, 5, 6290-6299. [CrossRef] 
123. Wei, J.; Wang, B.; Li, Z.; Wu, Z.; Zhang, M.; Sheng, N.; Liang, Q.; Wang, H.; Chen, S. A 3D-Printable TEMPO-Oxidized Bacterial Cellulose/Alginate Hydrogel with Enhanced Stability via Nanoclay Incorporation. Carbohydr. Polym. 2020, 238, 116207. [CrossRef]

124. Jiang, Y.; Zhou, J.; Yang, Z.; Liu, D.; Xv, X.; Zhao, G.; Shi, H.; Zhang, Q. Dialdehyde cellulose nanocrystal/gelatin hydrogel optimized for 3D printing applications. J. Mater. Sci. 2018, 53, 11883-11900. [CrossRef]

125. Heggset, E.B.; Strand, B.L.; Sundby, K.W.; Simon, S.; Chinga-Carrasco, G.; Syverud, K. Viscoelastic properties of nanocellulose based inks for 3D printing and mechanical properties of CNF/alginate biocomposite gels. Cellulose 2019, 26, 581-595. [CrossRef]

126. Huang, L.; Du, X.; Fan, S.; Yang, G.; Shao, H.; Li, D.; Caod, C.; Zhu, Y.; Zhua, M.; Zhang, Y. Bacterial cellulose nanofibers promote stress and fidelity of 3D-printed silk based hydrogel scaffold with hierarchical pores. Carbohydr. Polym. 2019, 221, 146-156. [CrossRef]

127. Markstedt, K.; Escalante, A.; Toriz, G.; Gatenholm, P. Biomimetic Inks Based on Cellulose Nanofibrils and Cross-Linkable Xylans for 3D Printing. ACS Appl. Mater. Interfaces 2017, 9, 40878-40886. [CrossRef]

128. Mohan, T.; Dobaj Štiglic, A.; Beaumont, M.; Konnerth, J.; Gürer, F.; Makuc, D.; Maver, U.; Gradišnik, L.; Plavec, J.; Kargl, R.; et al. Generic Method for Designing Self-Standing and Dual Porous 3D Bioscaffolds from Cellulosic Nanomaterials for Tissue Engineering Applications. ACS Appl. Bio Mater. 2020, 3, 1197-1209. [CrossRef]

129. Li, Y.Y.; Zhu, H.L.; Wang, Y.B.; Ray, U.; Zhu, S.Z.; Dai, J.Q.; Chen, C.J.; Fu, K.; Jang, S.; Henderson, D.; et al. Cellulose-nanofiber-enabled $3 \mathrm{~d}$ printing of a carbon-nanotube microfiber network. Small Methods 2017, 1, 1700222. [CrossRef]

130. Li, V.C.F.; Mulyadi, A.; Dunn, C.K.; Deng, Y.; Qi, H.J. Direct Ink Write 3D Printed Cellulose Nanofiber Aerogel Structures with Highly Deformable, Shape Recoverable, and Functionalizable Properties. ACS Sustain. Chem. Eng. 2018, 6, 2011-2022. [CrossRef]

131. Li, V.C.F.; Kuang, X.; Hamel, C.M.; Roach, D.; Deng, Y.; Qi, H.J. Cellulose nanocrystals support material for 3D printing complexly shaped structures via multi-materials-multi-methods printing. Addit. Manuf. 2019, 28, 14-22. [CrossRef]

132. Sultan, S.; Mathew, A.P. 3D printed porous cellulose nanocomposite hydrogel scaffolds. J. Vis. Exp. 2019, 146, 59401. [CrossRef]

133. Park, J.S.; Kim, T.; Kim, W.S. Conductive Cellulose Composites with Low Percolation Threshold for 3D Printed Electronics. Sci. Rep. 2017, 7, 1-10. [CrossRef]

134. Siqueira, G.; Kokkinis, D.; Libanori, R.; Hausmann, M.K.; Gladman, A.S.; Neels, A.; Tingaut, P.; Zimmermann, T.; Lewis, J.A.; Studart, A.R. Cellulose Nanocrystal Inks for 3D Printing of Textured Cellular Architectures. Adv. Funct. Mater. 2017, 27, 1604619. [CrossRef]

135. Li, L.; Zhu, Y.; Yang, J. 3D bioprinting of cellulose with controlled porous structures from NMMO. Mater. Lett. 2018, 210, 136-138. [CrossRef]

136. Thibaut, C.; Denneulin, A.; Rolland du Roscoat, S.; Beneventi, D.; Orgéas, L.; Chaussy, D. A fibrous cellulose paste formulation to manufacture structural parts using 3D printing by extrusion. Carbohydr. Polym. 2019, 212, 119-128. [CrossRef]

137. Kuzmenko, V.; Karabulut, E.; Pernevik, E.; Enoksson, P.; Gatenholm, P. Tailor-made conductive inks from cellulose nanofibrils for 3D printing of neural guidelines. Carbohydr. Polym. 2018, 189, 22-30. [CrossRef]

138. Mohan, D.; Khairullah, N.F.; How, Y.P.; Sajab, M.S.; Kaco, H. 3D Printed Laminated $\mathrm{CaCO}_{3}-\mathrm{Nanocellulose}$ Films as Controlled-Release 5-Fluorouracil. Polymers 2020, 12, 986. [CrossRef] [PubMed]

139. Borujeni, S.H.; Mirdamadian, S.Z.; Varshosaz, J.; Taheri, A. Three-dimensional (3D) printed tablets using ethyl cellulose and hydroxypropyl cellulose to achieve zero order sustained release profile. Cellulose 2020, 27, 1573-1589. [CrossRef]

140. Chen, R.-D.; Huang, C.-F.; Hsu, S.-H. Composites of waterborne polyurethane and cellulose nanofibers for 3D printing and bioapplications. Carbohydr. Polym. 2019, 212, 75-88. [CrossRef] [PubMed]

141. Altun, E.; Ekren, N.; Kuruca, S.E.; Gunduz, O. Cell studies on electrohydrodynamic (ehd)-3d-bioprinted bacterial cellulose $\backslash$ polycaprolactone scaffolds for tissue engineering. Mater. Lett. 2019, 234, 163-167. [CrossRef]

142. Espinosa, E.; Filgueira, D.; Rodríguez, A.; Chinga-Carrasco, G. Nanocellulose-Based Inks—Effect of Alginate Content on the Water Absorption of 3D Printed Constructs. Bioengineering 2019, 6, 65. [CrossRef] 
143. Kanjou, M.M.; Abdulhakim, H.; de Olyveira, G.M.; Basmaji, P. 3-D Print Celulose Nanoskin: Future Diabetic Wound Healing. J. Biomater. Nanobiotechnol. 2019, 10, 190-195. [CrossRef]

144. Huang, H.; Dean, D. 3-D printed porous cellulose acetate tissue scaffolds for additive manufacturing. Addit. Manuf. 2020, 31, 100927. [CrossRef]

145. Meng, X.; Yang, J.; Liu, Z.; Lu, W.; Sun, Y.; Dai, Y. Non-contact, fibrous cellulose acetate/aluminum flexible electronic-sensor for humidity detecting. Compos. Commun. 2020, 20, 100347. [CrossRef]

146. Cao, D.; Cing, Y.; Tantratian, K.; Wang, X.; Ma, Y.; Mukhopadhyay, A.; Cheng, Z.; Zhang, Q.; Jiao, Y.; Chen, L.; et al. 3D printed high-performance lithium metal microbatteries enabled by nanocellulose. Adv. Mater. 2019, 31, 1807313. [CrossRef]

147. Françon, H.; Wang, Z.; Marais, A.; Mystek, K.; Piper, A.; Granberg, H.; Malti, A.; Gatenholm, P.; Larsson, P.A.; Wågberg, L. Ambient-Dried, 3D-Printable and Electrically Conducting Cellulose Nanofiber Aerogels by Inclusion of Functional Polymers. Adv. Funct. Mater. 2020, 30, 1909383. [CrossRef]

148. Kim, T.; Bao, C.; Hausmann, M.; Siqueira, G.; Zimmermann, T.; Kim, W.S. 3D printed disposable wireless ion sensors with biocompatible cellulose composites. Adv. Electron. Mater. 2019, 5, 1800778. [CrossRef]

149. Lille, M.; Nurmela, A.; Nordlund, E.; Metsä-Kortelainen, S.; Sozer, N. Applicability of protein and fiber-rich food materials in extrusion-based 3D printing. J. Food Eng. 2017, 220, 20-27. [CrossRef]

150. Holland, S.; Foster, T.; MacNaughtan, W.; Tuck, C. Design and characterisation of food grade powders and inks for microstructure control using 3D printing. J. Food Eng. 2018, 220, 12-19. [CrossRef]

151. Tenhunen, T.M.; Moslemian, O.; Kammiovirta, K.; Harlin, A.; Kääriäinen, P.; Österberg, M.; Tammelin, T.; Orelma, H. Surface tailoring and design-driven prototyping of fabrics with 3D-printing: An all-cellulose approach. Mater. Des. 2018, 140, 409-419. [CrossRef]

152. Nechyporchuk, O.; Yu, J.; Nierstrasz, V.A.; Bordes, R. Cellulose Nanofibril-Based Coatings of Woven Cotton Fabrics for Improved Inkjet Printing with a Potential in E-Textile Manufacturing. ACS Sustain. Chem. Eng. 2017, 5, 4793-4801. [CrossRef]

153. Wang, J.; Gardner, D.J.; Stark, N.M.; Bousfield, D.W.; Tajvidi, M.; Cai, Z. Moisture and Oxygen Barrier Properties of Cellulose Nanomaterial-Based Films. ACS Sustain. Chem. Eng. 2018, 6, 49-70. [CrossRef]

154. Nicharat, A.; Shirole, A.; Foster, E.J.; Weder, C. Thermally activated shape memory behavior of melt-mixed polyurethane/cellulose nanocrystal composites. J. Appl. Polym. Sci. 2017, 134, 45033. [CrossRef]

155. Cudjoe, E.; Khani, S.; Way, A.E.; Hore, M.J.A.; Maia, J.; Rowan, S.J. Biomimetic Reversible Heat-Stiffening Polymer Nanocomposites. ACS Cent. Sci. 2017, 3, 886-894. [CrossRef]

156. Wang, M.; Tian, X.; Ras, R.H.A.; Ikkala, O. Sensitive Humidity-Driven Reversible and Bidirectional Bending of Nanocellulose Thin Films as Bio-Inspired Actuation. Adv. Mater. Interfaces 2015, 2, 1500080. [CrossRef]

157. Kuang, Y.; Chen, C.; Cheng, J.; Pastel, G.; Li, T.; Song, J.; Jiang, F.; Li, Y.; Zhang, Y.; Jang, S.-H.; et al. Selectively aligned cellulose nanofibers towards high-performance soft actuators. Extrem. Mech. Lett. 2019, 29, 100463. [CrossRef]

158. Mredha, M.T.I.; Le, H.H.; Tran, V.T.; Trtik, P.; Cui, J.X.; Jeon, I. Anisotropic tough multilayer hydrogels with programmable orientation. Mater. Horiz. 2019, 6, 1504-1511. [CrossRef]

159. Bumbudsanpharoke, N.; Kwon, S.; Lee, W.; Ko, S. Optical response of photonic cellulose nanocrystal film for a novel humidity indicator. Int. J. Biol. Macromol. 2019, 140, 91-97. [CrossRef] [PubMed]

160. Khiabani, P.S.; Soeriyadi, A.H.; Reece, P.J.; Gooding, J.J. Paper-Based Sensor for Monitoring Sun Exposure. ACS Sens. 2016, 1, 775-780. [CrossRef]

161. Koga, H.; Nogi, M.; Isogai, A. Ionic Liquid Mediated Dispersion and Support of Functional Molecules on Cellulose Fibers for Stimuli-Responsive Chromic Paper Devices. ACS Appl. Mater. Interfaces 2017, 9, 40914-40920. [CrossRef]

162. Nau, M.; Seelinger, D.; Biesalski, M. Independent Two Way Switching of the Wetting Behavior of Cellulose-Derived Nanoparticle Surface Coatings by Light and by Temperature. Adv. Mater. Interfaces 2019, 6, 1900378. [CrossRef]

163. Liu, X.; Li, M.; Zheng, X.; Retulainen, E.; Fu, S. Dual Light- and pH-Responsive Composite of Polyazo-Derivative Grafted Cellulose Nanocrystals. Materials 2018, 11, 1725. [CrossRef]

164. Ortega, G.; Pérez-Rodríguez, S.; Reguera, E. Magnetic paper-based ELISA for IgM-dengue detection. RSC Adv. 2017, 7, 4921-4932. [CrossRef]

165. Mo, Z.; Guo, H.; Wang, Y.; Yin, H.; Yang, C. Surface modification of graphene oxide sheets on magnetic particles for magnetic paper. J. Alloys Compd. 2017, 695, 2525-2531. [CrossRef] 
166. Rajala, S.; Siponkoski, T.; Sarlin, E.; Mettänen, M.; Vuoriluoto, M.; Pammo, A.; Juuti, J.; Rojas, O.J.; Franssila, S.; Tuukkanen, S. Cellulose nanofibril film as a piezoelectric sensor material. ACS Appl. Mater. Interfaces 2016, 8, 15607-15614. [CrossRef]

167. Zheng, Q.; Zhang, H.; Mi, H.; Cai, Z.; Ma, Z.; Gong, S. High-performance flexible piezoelectric nanogenerators consisting of porous cellulose nanofibril (CNF)/poly(dimethylsiloxane) (PDMS) aerogel films. Nano Energy 2016, 26, 504-512. [CrossRef]

168. Alam, M.M.; Mandal, D. Native cellulose microfiber-based hybrid piezoelectric generator for mechanical energy harvesting utility. ACS Appl. Mater. Interfaces 2016, 8, 1555-1558. [CrossRef]

169. Yang, H.; Choi, S.E.; Kim, D.; Park, D.; Lee, D.; Choi, S.; Nam, Y.S.; Kim, J.W. Color-spectrum-broadened ductile cellulose films for vapor-pH -responsive colorimetric sensors. J. Ind. Eng. Chem. 2019, 80, 590-596. [CrossRef]

170. Gladman, A.S.; Matsumoto, E.A.; Nuzzo, R.G.; Mahadevan, L.; Lewis, J.A. Biomimetic 4D printing. Nat. Mater. 2016, 15, 413-418. [CrossRef] [PubMed]

171. Mulakkal, M.C.; Trask, R.S.; Ting, V.P.; Seddon, A.M. Responsive cellulose-hydrogel composite ink for 4D printing. Mater. Des. 2018, 160, 108-118. [CrossRef]

172. Giachini, P.A.G.S.; Gupta, S.S.; Wang, W.; Wood, D.; Yunusa, M.; Baharlou, E.; Sitti, M.; Menges, A. Additive manufacturing of cellulose-based materials with continuous, multidirectional stiffness gradients. Sci. Adv. 2020, 6, eaay0929. [CrossRef] [PubMed]

173. Stolz, B.; Mülhaupt, R. Cellular, Mineralized, and Programmable Cellulose Composites Fabricated by 3D Printing of Aqueous Pastes Derived from Paper Wastes and Microfibrillated Cellulose. Macromol. Mater. Eng. 2020, 305, 1900740. [CrossRef]

174. Uchida, T.; Onoe, H. 4D Printing of Multi-Hydrogels Using Direct Ink Writing in a Supporting Viscous Liquid. Micromachines 2019, 10, 433. [CrossRef]

175. Oladapo, B.I.; Adebiyi, A.V.; Elemure, E.I. Microstructural 4D printing investigation of ultra-sonication biocomposite polymer. J. King Saud Univ.-Eng. Sci. 2019, 10, 1-7. [CrossRef]

176. Oladapo, B.I.; Oshin, E.A.; Olawumi, A.M. Nanostructural computation of 4D printing carboxymethylcellulose (CMC) composite. Nanostruct. Nanoobjects 2020, 21, 100423. [CrossRef]

(C) 2020 by the authors. Licensee MDPI, Basel, Switzerland. This article is an open access article distributed under the terms and conditions of the Creative Commons Attribution (CC BY) license (http://creativecommons.org/licenses/by/4.0/). 